\title{
The Late Triassic Bivalve Monotis in Accreted Terranes of Alaska
}

By N.J. Silberling, J.A. Grant-Mackie, and K.M. Nichols

U.S. GEOLOGICAL SURVEY BULLETIN 2151 


\title{
U.S. DEPARTMENT OF THE INTERIOR BRUCE BABBITT, Secretary
}

\author{
U.S. GEOLOGICAL SURVEY \\ Gordon P. Eaton, Director
}

For sale by U.S. Geological Survey, Information Services

Box 25286, Federal Center

Denver, CO 80225

\begin{abstract}
Any use of trade, product, or firm names in this publication is for descriptive purposes only and does not imply endorsement by the U.S. Government
\end{abstract}

Library of Congress Cataloging-in-Publication Data

Silberling, N. J. (Norman John), 1928-

The Late Triassic bivalve Monotis in accreted terranes of Alaska / by N.J. Silberling, J.A. Grant-Mackie, and K.M. Nichols.

p. cm.-(U.S. Geological Survey bulletin ; 2151)

Includes bibliographical references.

Supt. of Docs. no. : I 19. 3: 2151

1. Monotis-Alaska. 2. Paleontology-Triassic. 3. Animals, FossilAlaska. I. Grant-Mackie, J.A. II. Nichols, K. M. (Kathryn Marion), 1946III. Title. IV. Series.

QE75.B9 no. 2151

[QE812.M6]

$557.3 \mathrm{~s}-\mathrm{dc} 20$

[564'.11] 


\section{CONTENTS}

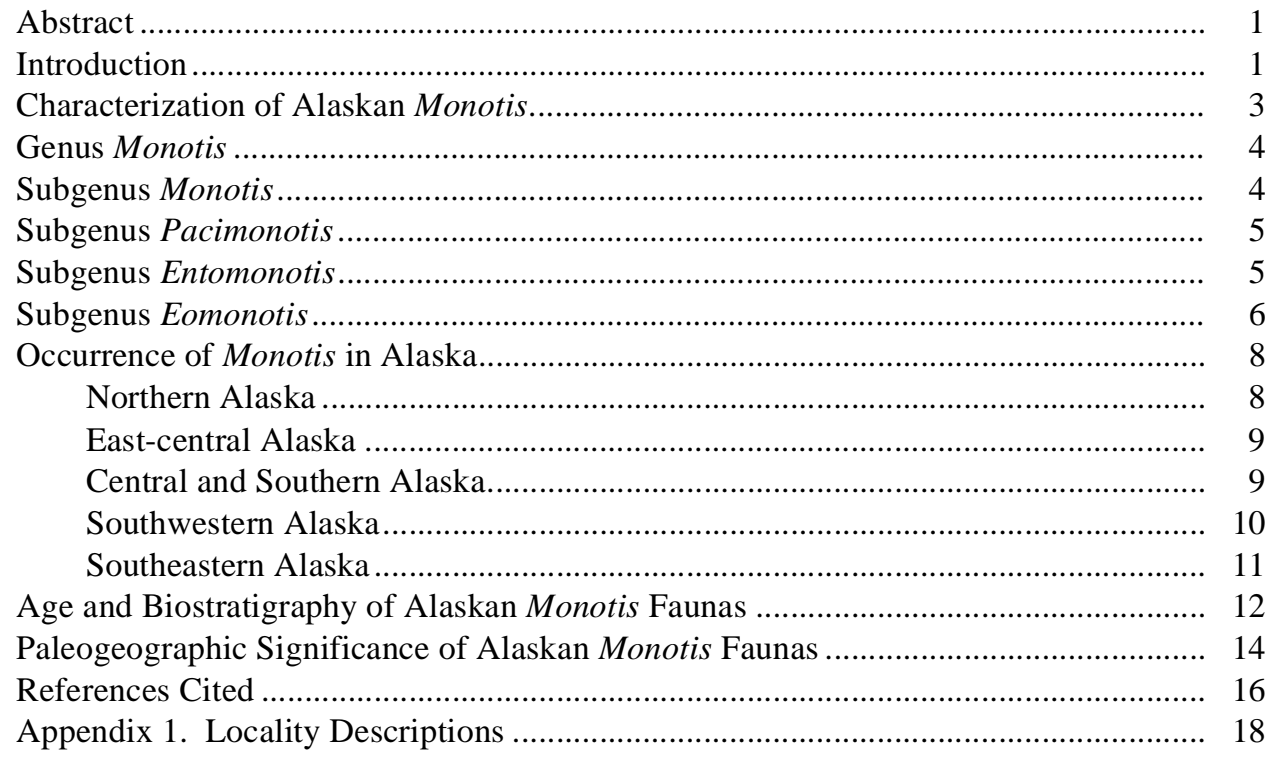

\section{PLATES}

[Plates follow appendix]

1. Alexander terrane.

2. Peninsular terrane.

3. Wrangellia terrane.

4. Wrangellia, Susitna, Chulitna terranes.

5. Nixon Fork and McKinley terranes.

6. Non-accretionary Upper Yukon region.

7. Upper Yukon region and Endicott Mountains subterrane.

8. Endicott Mountains subterrane.

9. Endicott Mountains subterrane.

10. North Slope subterrane.

11. North Slope subterrane.

\section{FIGURES}

1. Index map showing location of accreted terranes containing Monotis-bearing strata in Alaska and adjacent Canada

2. Diagrammatic sketch of left valve of Monotis illustrating morphologic features and terminology..

3. Chart showing relative stratigraphic ranges of Alaskan Monotis species and subspecies

4. Checklist showing occurrence of Monotis species in accretionary and non-accretionary Alaska, and in the Stikinia terrane of Canada . 


\title{
THE LATE TRIASSIC BIVALVE MONOTIS IN ACCRETED TERRANES OF ALASKA
}

\author{
By N.J. Silberling, J.A. Grant-Mackie, ${ }^{1}$ and K.M. Nichols
}

\begin{abstract}
Late Triassic bivalves of the genus Monotis occur in at least 16 of the lithotectonic terranes and subterranes that together comprise nearly all of Alaska, and they also occur in the Upper Yukon region of Alaska where Triassic strata are regarded as representing non-accretionary North America. On the basis of collections made thus far, 14 kinds of Monotis that differ at the species or subspecies level can be recognized from Alaska. These are grouped into the subgenera Monotis (Monotis), M. (Pacimonotis), M. (Entomonotis), and $M$. (Eomonotis). In places, Monotis shells of one kind or another occur in rock-forming abundance.

On the basis of superpositional data from Alaska, as well as from elsewhere in North America and Far Eastern Russia, at least four distinct biostratigraphic levels can be discriminated utilizing Monotis species. Different species of M. (Eomonotis) characterize two middle Norian levels, both probably within the upper middle Norian Columbianus Ammonite Zone. Two additional levels are recognized in the lower upper Norian Cordilleranus Ammonite Zone utilizing species of $M$. (Monotis) or M. (Entomonotis), both of which subgenera are restricted to the late Norian.

An attached-floating mode of life is commonly attributed to Monotis; thus, these bivalves would have been pseudoplanktonic surface dwellers that were sensitive to surface-water temperature and paleolatitude. Distinctly different kinds of Monotis occur at different paleolatitudes along the Pacific and Arctic margins of the North American craton inboard of the accreted terranes. Comparison between these craton-bound Monotis faunas and those of the Alaskan terranes indicates that all of the Monotis-bearing terranes in southern Alaska south of the Denali fault were paleoequatorial in latitude during Late Triassic time. Among these terranes, the Alexander terrane was possibly in the southern hemisphere at that time. Terranes of northern Alaska, on the other hand, represent middle, possibly high-middle, northern paleolatitudes.
\end{abstract}

\footnotetext{
${ }^{1}$ University of Auckland, Auckland, New Zealand.
}

\section{INTRODUCTION}

Thin-shelled, pecten-like bivalves of the genus Monotis are widespread and locally abundant in Upper Triassic rocks of Alaska (fig. 1). These easily recognized fossils have been found in 16 of the 50 accreted tectonostratigraphic terranes and subterranes recognized by Jones and others (1987) as forming nearly all of Alaska. Each of these terranes and subterranes is fault-bounded and records a distinct geologic history; their tectonic displacement relative to each other and to the North American craton ranges from tens to thousands of kilometers (Jones and others, 1986). Not only are Monotis faunas useful for dating and correlating the strata of the terranes in which they occur, but the paleolatitudinal distribution of different species of Monotis varied, and thus they also provide important paleogeographic constraints for interpreting the displacement histories of the various terranes. The major biogeographic conclusions that can be drawn from Alaskan Monotis faunas have previously been discussed by Tozer (1982) and Silberling (1985).

The purposes of this report are to enlarge upon these general conclusions and to provide needed documentation at a refined taxonomic level of the Monotis faunas presently known from Alaskan accreted terranes. Additionally, we hope that the illustrations, diagnoses, and identification key will enable Alaskan geologists to use this report as a field guide to the various species of Monotis. Not only are the various species useful in the field for general age and biogeographic interpretation but, in places such as northern Alaska, they also occur in profusion in an easily recognized succession of different species. In such places, they thus can be a valuable aid in deciphering the structure of intricately deformed strata.

The Alaskan Monotis faunas on which this study is based are part of the U.S. Geological Survey paleontological collections currently housed in the Denver, Colorado, field center. These collections and their supporting locality and stratigraphic data represent the effort of many geologists involved with U.S. Geological Survey research programs in Alaska since the early 1900's. In all, Monotis is known from several hundred geographically or stratigraphically different 


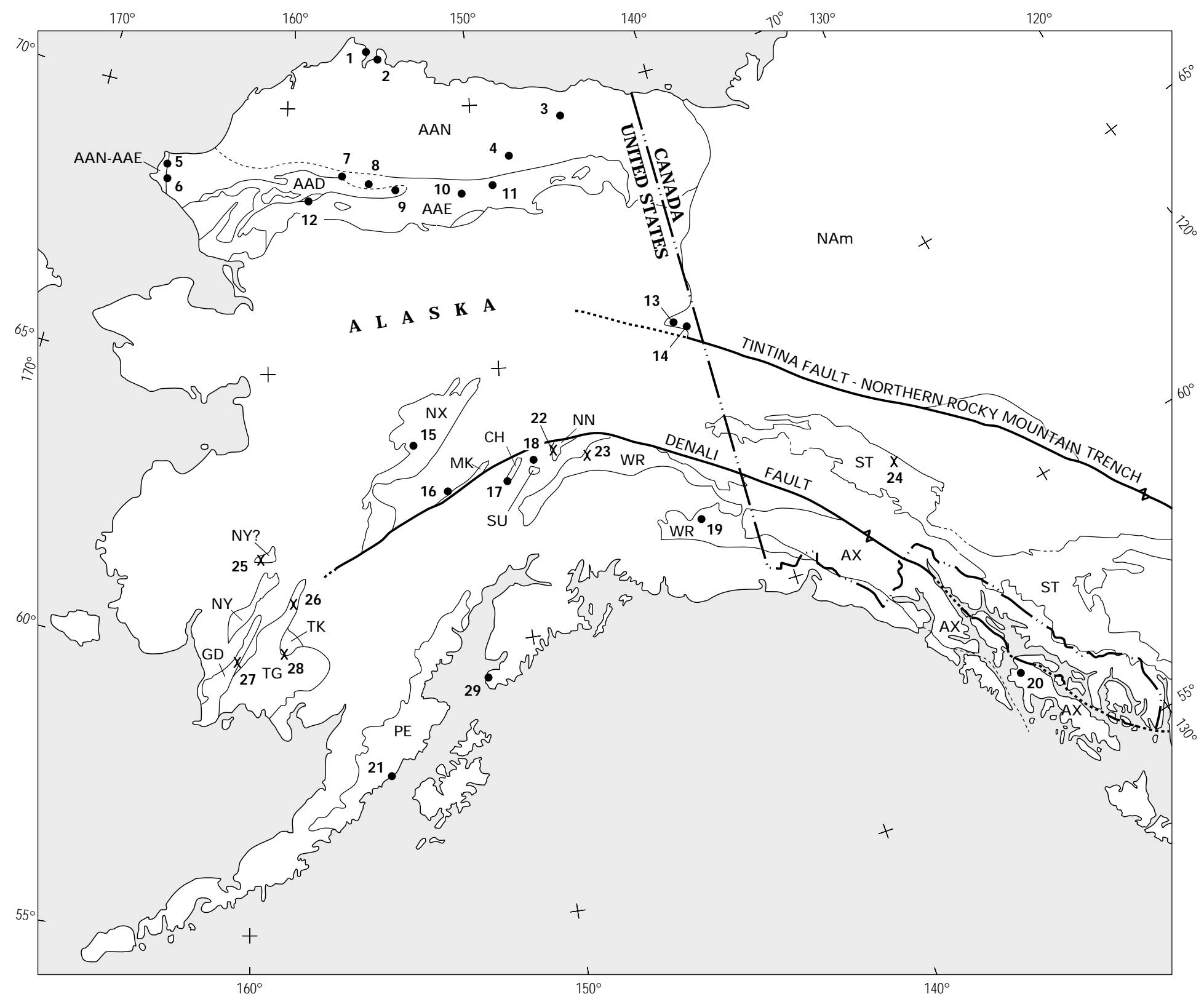


Alaskan localities. Specimens figured herein that were collected by the senior author are from localities originally discovered and put into stratigraphic context by E.E. Brabb, A.F. Buddington, M.C. Churkin, E.M. MacKevett, F.H. Moffit, R.M. Overbeck, W.W. Patton, Jr., I.L. Tailleur, and others. Especially significant stratigraphically controlled Monotis collections from Alaska have been made by M.C. Churkin, R.L. Detterman, C.G. Mull, I.L. Tailleur, and H.A. Tourtelot.

The selection and preparation of materials for this study and the interpretation of their geologic settings were largely the work of Silberling and Nichols, whereas the formulation of taxonomic concepts and final identifications of the specimens illustrated herein were for the most part done by GrantMackie during a visit to the USGS Denver field center of about 2 months in late 1985 as part of a Fulbright Travel Grant.

\section{CHARACTERIZATION OF ALASKAN MONOTIS}

Fourteen different kinds of Monotis are presently known from Alaska. All of these are characterized and illustrated in the present study, even though some are regarded only as subspecies and some remain indefinite in terms of specific or subspecific assignment. Representation of the various taxa varies widely; some are extremely common, their shells occurring locally in rock-forming abundances, whereas others are known only from one or two specimens. Because one of the principal objectives of this study is to record the Monotis faunas of the various Alaskan terranes, specimens that document the occurrence of a taxon in a certain terrane are illustrated even though they may not be particularly well preserved. Nevertheless, for each species or subgenus the most morphologically complete specimens available in the Alaskan collections are figured and characterized. Some taxa are illustrated from more than one terrane or subterrane.

Figure 1 (facing page). Index map showing location of accreted lithotectonic terranes containing Monotis-bearing strata in Alaska and adjacent parts of Canada. Numbered solid dots, localities of specimens illustrated on plates 1-11; numbered X's, other significant occurrences of Monotis discussed in text. NAm (shaded area), non-accretionary Phanerozoic North American rocks. Symbols for accreted terranes: AX, Alexander terrane; AAD, DeLong Mountains subterrane, Arctic Alaska terrane; AAE, Endicott Mountains subterrane, Arctic Alaska terrane; AAN, North Slope subterrane, Arctic Alaska terrane; AAN-AAE, subterrane transitional from AAN to AAE; $\mathrm{CH}$, Chulitna terrane; GD, Goodnews terrane; MK, McKinley terrane; NN, Nenana terrane; NX, Nixon Fork terrane; NY, Nyac terrane; PE, Peninsular terrane; ST, Stikinia terrane; SU, Susitna terrane; TG, Togiak terrane; TK, Tikchik terrane; WR, Wrangellia terrane.
Taxonomic assignments adopted here are strictly circumscribed by means of measureable parameters and the presence or absence of particular morphologic features. The terminology used to describe the morphology of Monotis shells is illustrated in figure 2. Although historically one of us (NJS) has had a proclivity towards population-based, morphologically variable species concepts, the more operational biometric approach advocated by Grant-Mackie (Grant-Mackie and Silberling, 1990) is followed here. This approach offers the two-fold advantage of greater objectivity and of making the various taxa considered here directly comparable to those characterized by Grant-Mackie from elsewhere on the Pacific margin, principally New Zealand (Grant-Mackie, 1981). Taxonomic descriptions of the subgenera, and of some of the species and subspecies, of Alaskan Monotis have been published recently by GrantMackie and Silberling (1990), and the reader is directed to this paper for systematic and biometric data.

The genus Monotis is morphologically distinct from other kinds of generally pecten-like bivalves and is generally placed by itself in the separate Family Monotidae. Recognition of four subgenera within the genus is useful in that the subgenera themselves have temporal and paleogeographic significance. Starting with the genus Monotis itself, the various subgenera, species, and subspecies of Alaskan Monotis are briefly diagnosed and discussed herein, and a key to their identification is provided following.

1. Adult size small to medium; posterior ear ribbed. Subgenus M. (Eomonotis) ............................................... 2 Medium to large size; posterior ear smooth ....................... 9

2. Left valve much more inflated than right.............................. 3 Left valve only little more inflated than right ........................... 4

3. Ribs very fine and dense; about 40 primary ribs ..n.sp. aff. M. (Eo.) inaequivalvis

Ribs stronger; about 18 primary ribs.....................M (Eo.) jakutica

4. Ribs fine, narrow, relatively sharp ……................................ 5

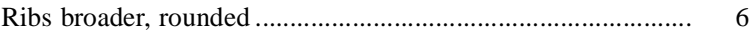

5. Ribs crowded; about 25 primary ribs; secondary ribs of similar strength................................................ (Eo.) typica

Ribs well differentiated in three orders; about 30 primary

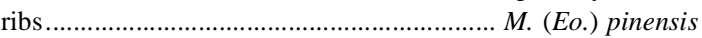

6. Secondary ribs inserted early .............................................. 7

Secondary ribs inserted late .................................................... 8

7. Primary ribs about 30 ; secondary ribs inserted at mid-height; anterodorsal margin "pouts" ................. (Eo.) daonellaeformis

Primary ribs about 20; faint tertiary ribs inserted marginally................................ n.sp. aff. M. (Eo.) anjuensis

8. Primary ribs $25-30$; ribs tend to fade dorsally ........................................................... (Eo.) obtusicostata

Primary ribs about 30 ; ribs do not weaken dorsally .................................................... (Eo.) anjuensis

9. Ribs narrow and sharp; subequivalved, left valve little more inflated than right ............................................................ 10

Ribs relatively coarse; left valve much more inflated than right ............. Subgenus Entomonotis................................. 13

10. Valve obliquely oval; primary ribs 18 or more Subgenus Monotis ............................................................. 12

Valve subcircular to posteroventrally elongate; different orders of ribbing well differentiated Subgenus Pacimonotis. 


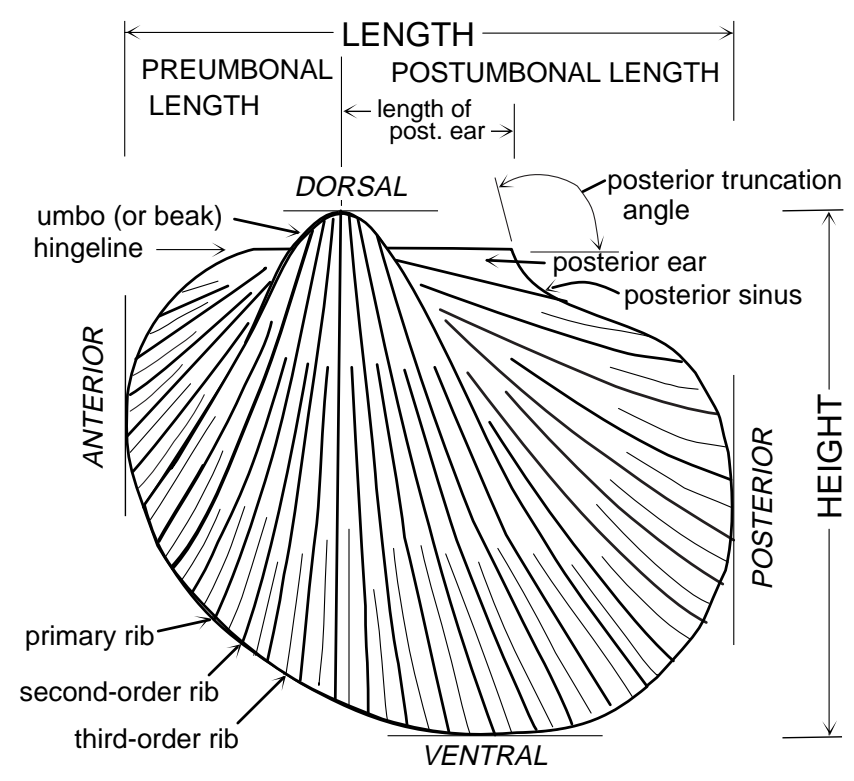

Figure 2. Diagrammatic left valve of a relatively inflated Monotis shell illustrating principal morphologic features and morphologic terms used herein.

11. About 15 primary ribs; concentric striae conspicuous, especially in interstices between ribs............................ (P.) subcircularis

12. Primary ribs about 20; concentric striae commonly present......................................................... (M.) haueri

Primary ribs about 30 ; concentric striae rarely present........................................................... (M.) alaskana

13. Ribs moderately narrow, well differentiated......................... 14 Ribs broad, rounded; about 16 primary ribs, few secondary ribs ...................................................... (En.) pachypleura

14. About 14 primary ribs .............................. (En.) ochotica ochotica About 18 primary ribs.................... (En.) cf. ochotica densistriata

\section{Genus MONOTIS Bronn, 1830}

Diagnosis.-Pecten-like bivalves that are thin shelled relative to their length (fig. 2) which rarely exceeds $100 \mathrm{~mm}$; mature shells of the smallest species are about $20 \mathrm{~mm}$ in length. Viewed end on, subequivalved to strongly inequivalved, wherein the left valve may be much more inflated than the right, which may be nearly flat. In lateral view, outline of the shell subquadrate, subcircular, or obliquely suboval; usually inequilateral in shape having the beak shifted anteriorly and the greatest height shifted posteriorly. Dorsal margin straight and comarginal with a distinct posterior ear that is separated from the posterodorsal margin by the concave-outward curve of the posterior sinus (see fig. 2). Depth of posterior sinus varies from shallow to deep, and the posterior angle (fig. 2) varies from $90^{\circ}$ to $160^{\circ}$, depending on the subgenus. Anterior (or byssal) ear on right valve relatively very small and projected inwards so as to be inconspicuous; no anterior ear on left valve on which the anterodorsal margin is evenly rounded. Sculpture of rounded, regular, radial ribs that in a few species may become obsolete with growth or be absent. On ventrolateral surface two or more orders (that is, primary, secondary, tertiary, and so on) of radial ribs, generally of distinctly different strength, produce an alternating pattern of coarse-fine-coarse-fine, and so on, or coarsefine-medium-fine-coarse-fine, and so on. In some species ribs and interspaces are crenulated by fine, evenly spaced, concentric growth striae (for example, pl. 2, fig. 13). Posterior ear may bear radial ribs or be smooth, depending on the subgenus.

Remarks.-Specimens of Monotis, even where preserved only as flattened impressions, are nearly unmistakable among other kinds of bivalve fossils by virtue of their size, characteristic shape that results from the prominent posterior ear, and radial ribbing. Although not strictly true, the inconspicuous nature of the anterior ear, as compared to the posterior ear, gives the genus its name, meaning "one-eared." In the older literature, the common North American species Monotis subcircularis was generally included in the typically late Paleozoic genus Pseudomonotis, meaning "falsely one-eared," because the inconspicuous anterior ear was noticed on this New World species long before it was discovered on European species originally included in the exclusively Late Triassic genus Monotis.

\section{Subgenus MONOTIS Bronn, 1830}

Diagnosis.-Small- to medium-size Monotis having an obliquely oval outline. Subequivalved, the left valve being only a little more inflated than the nearly flat right valve. The posterior ear is smooth and well separated from the rest of the valve by a moderately deep posterior sinus; posterior angle $130^{\circ} \pm 15^{\circ}$. Radial ribs are fine and characteristically tend to weaken and become wavy posterodorsally. Concentric striae not always present.

Remarks. - This subgenus is distinguished by its modest size, notably oblique shape, relatively abundant, regular ribs, and smooth, well-differentiated posterior ear.

\section{MONOTIS (MONOTIS) ALASKANA Smith, 1927}

${ }^{2}$ Plate 2, figures 1-7; plate 3, figures 4-7, ?14-15; plate 4, figures 6-7

Diagnosis.-Medium size M. (Monotis) up to $50 \mathrm{~mm}$ long. Postumbonal length up to twice anterior length and 2-3 times length of posterior ear that is truncated posteriorly at $130^{\circ} \pm 15^{\circ}$. Primary ribs number $30 \pm 5$; secondary ribs inserted at valve height of about $10 \mathrm{~mm}$, and tertiary ribs, if present, irregularly inserted at valve height of about $25 \mathrm{~mm}$. Concentric sculpture closely spaced and faint, if visible at all.

Remarks.-Within the subgenus this species is distinguished by its numerous, narrow, crowded ribs and weak development of concentric striae. At times specimens of $M$.

\footnotetext{
${ }^{2}$ A query (?) before a plate figure number indicates some uncertainity in the identification of the particular specimen(s). It is used in lieu of the designation "cf." where Monotis specimens of both certain and uncertain species assignment are listed under the same species-name heading in the text.
} 
(M.) alaskana from Alaska and elsewhere in North America have been referred to the typically Tethyan species $M$. $(M$.) salinaria (Schlotheim), the type species of the genus and subgenus, and $M$. salinaria has been regarded as a senior synonym of $M$. alaskana. However, careful comparison of Monotis in the extensive collections of the U.S. Geological Survey with topotype specimens of $M$. salinaria from Siriuskogel, Austria (pl. 4, figs. 11-13), shows that none of the North American specimens belongs in this species, which has about 22 primary ribs compared to about 30 in $M$. alaskana (Grant-Mackie and Silberling, 1990).

\section{MONOTIS (MONOTIS) HAUERI Kittl, 1912}

Plate 3, ?figures 8-13; plate 8, figure 9

Diagnosis.-Moderately large Monotis s.s. up to $70 \mathrm{~mm}$ in length. Outline markedly oblique with the postumbonal length as much as four times the preumbonal length. Primary ribs number 17-20 and are strongly developed compared to the secondary ribs. Regular, dense, concentric striae commonly preserved.

Remarks.-This species differs from $M$. alaskana in having stronger and many fewer primary ribs, more conspicuous concentric ornamentation, and on the average a more obliquely oval shape. This species and M. subcircularis are easily confused, especially in poorly preserved or incomplete material, because of similarities of inflation, outline, and sculptural style. They are readily separated, however, by the small difference in the average number of primary ribs, intermediate population samples not being represented. Some previously published identifications of North American specimens as $M$. subcircularis should be reassigned to $M$. haueri as defined biometrically by Grant-Mackie and Silberling (1990), but this change would not affect geologic interpretations based on these specimens.

\section{Subgenus PACIMONOTIS Grant-Mackie and Silberling, 1990}

Diagnosis.-Moderate- to large-size Monotis having a subcircular to posteroventrally elongate outline. Subequivalved, both valves being only gently inflated. Posterior ear conspicuous, unsculptured, well separated from posterodorsal margin by a broad, deep sinus having a relatively acute posterior angle. Strong, narrow, abruptly rounded primary radial ribs differentiated from distinctly weaker subsidiary orders of ribbing. Most members have conspicuous dense, regular, concentric striae, especially in interstices between primary ribs.

Remarks. - The size, the distinct, smooth posterior ear, the subequivalve shape, and the nature of the ornamentation distinguish this subgenus. In Alaska it is represented only by M. (Pacimonotis) subcircularis; other species of the subgenus occur elsewhere around the circum-Pacific margin (Grant-Mackie and Silberling, 1990).

\section{MONOTIS (PACIMONOTIS) SUBCIRCULARIS Gabb, 1864}

Plate 1, figures 4-10, 13-14, 17-21; plate 2, figures 8-13; plate 3, figures $1-3, ? 18-19,20$; plate 4 , figures $1-5, ? 8-10$; plate 5 , figures $1-4$; plate 7 , figures ?1-3, 4-5; plate 8, ?figures 1-2; plate 9, figures 5-6; plate 11, ?figure 13

Diagnosis. - Large (up to $120 \mathrm{~mm}$ long) valves of subcircular to suboval outline. Postumbonal length about 1.5 times the anterior length and 2-4 times length of the posterior ear. Posterior angle $120^{\circ} \pm 10^{\circ}$. Number of primary ribs $15 \pm 5$; secondary ribs inserted early, at valve heights of 5-15 $\mathrm{mm}$, tertiary ribs at valve heights of 20-30 mm; fourth-order ribs irregularly present on valves larger than $45 \mathrm{~mm}$ high. Concentric striae conspicuous.

Remarks.-This is the largest, most widespread, and commonest North American Monotis, characterized by its regular concentric sculpture, low primary rib count coupled with a high total number of ribs, and relatively small, but distinct posterior ear having a low posterior truncation angle.

\section{Subgenus ENTOMONOTIS Marwick, 1935}

Diagnosis.-Medium- to large-size Monotis of obliquely suboval outline. Strongly inequivalve, having a conspicuously inflated left valve, the umbo of which projects dorsally well above the hingeline, and a flat to slightly inflated right valve possessing a much less conspicuous umbo. Posterior ear moderate to proportionally large, smooth, well separated from the rest of the valve by a distinct posterior sinus. Radial ribs relatively broad, rounded, and well differentiated; on some species ribs weaken and fade posteriorly. Concentric striae generally absent or poorly developed.

Remarks.-Distinguishing features of this subgenus are its strongly inequivalved shape and coarse ribbing.

\section{MONOTIS (ENTOMONOTIS) PACHYPLEURA (Teller, 1886)}

Plate 9, figures 1-4, 9-11

Diagnosis.-Medium size (up to $50 \mathrm{~mm}$ long), obliquely oval; postumbonal length 1.3-2.3 times the preumbonal length and about 2.5-3.0 times length of posterior ear. Inequivalve; inflation of right valve about half that of left. Ribs number $20 \pm 7$, with an average of $16-17$ broad, low, rounded primary ribs and a few much narrower, weaker, secondary ribs at the posteroventral margin. Interstices between ribs equal to or slightly narrower than primaries.

Remarks.-From other Alaskan species of this subgenus, M. (En.) pachypleura differs in its coarse, rounded ribbing, dominated by primary ribs.

\section{MONOTIS (ENTOMONOTIS) OCHOTICA OCHOTICA (Keyserling, 1848)}

Plate 9, figures 8, 12-13; plate 11, figures 1-3, ?4-7, 14-15

Diagnosis.-Medium- to large-size M. (Entomonotis) up to $70 \mathrm{~mm}$ long, obliquely oval, left valve well inflated, right valve almost flat. Beak at about anterior third of valve length; posterior valve length 2-3 times length of posterior 
ear. Ribs well spaced, rounded but relatively narrow; $14 \pm 2$ primary ribs; secondary ribs inserted early, weak tertiary ribs inserted later at $20-35 \mathrm{~mm}$ valve height. Fine concentric striae rarely present.

Remarks.-Alaskan specimens show the essential features of the typical Siberian $M$. (En.) ochotica sensu stricto and are assigned to this subspecies with confidence. They possess fewer and coarser ribs than $M$. (En.) o. densistriata, however defined, as discussed below, and yet have much narrower and more densely spaced ribs than $M$. (En.) pachypleura.

\section{MONOTIS (ENTOMONOTIS) sp. cf. M. (E.) OCHOTICA DENSISTRIATA (Teller, 1886)}

Plate 1, figures 1-3, 11-12

Diagnosis.-Small- to medium-size Monotis up to 40 $\mathrm{mm}$ long. Subcircular to obliquely suboval in outline, strongly inequivalve. Beak at the anterior third of the valve length; posterior valve length 2-4 times length of posterior ear. Ribs relatively sharp and narrow for M. (Entomonotis); primary ribs number $18 \pm 3$, much weaker secondary ribs inserted at valve height of $10 \pm 5 \mathrm{~mm}$, and some faint tertiary ribs inserted ventrally.

Remarks.-M. (En.) o. densistriata has been widely reported in the northern and western circum-Pacific, but examination by Grant-Mackie (unpub. data) of specimens so identified strongly suggests that many of these reported occurrences are incorrect. Misconceptions concerning this subspecies make its identification difficult outside of the former U.S.S.R., from where it was originally described. The form diagnosed above is smaller than many Asian specimens assigned to $M$. $o$. densistriata (for example, those illustrated by Kiparisova and others, 1966) and seems to be relatively longer and have a significantly larger posterior truncation angle of the posterior ear. Characteristics of the ribbing and inflation, however, are similar. The Alaskan form also has a higher posterior truncation angle of the posterior ear and a more inflated left valve than Canadian specimens assigned to the subspecies by Westermann (1962). Grant-Mackie, thus, would regard the Alaskan specimens as similar, rather than identical, to M. (En.) o. densistriata, pending better characterization of the Asian type material. Silberling, on the other hand, would treat the specimens figured here simply as immature variants of M. (Pacimonotis) subcircularis with which they occur in the same bed and with whose immature shells they might intergrade in the degree of inflation of the left valve and nature of the ribbing. This interpretation assumes that strongly inflated immature variants of $M$. subcircularis would be precluded from maturing and thus would be represented only by small shells.

\section{Subgenus EOMONOTIS Grant-Mackie, 1978}

Diagnosis.—Monotis of small or medium size, almost equivalve to moderately inequivalve, and with fine radial ribs that extend onto the posterior ear. Posterior ear is poorly separated from the rest of the shell, the posterior sinus being shallow or absent. Concentric sculpture is absent.

Remarks.-The prime morphologic distinctions of this subgenus are its poorly differentiated, ribbed posterior ear and the fine, numerous radial ribs.

\section{MONOTIS (EOMONOTIS) ANJUENSIS Bytschkov and Efimova, 1966}

$$
\text { Plate 5, figures 11-16 }
$$

Diagnosis.-Medium-size Monotis up to $40 \mathrm{~mm}$ long. Tranversely to obliquely oval, subequivalve, and of low inflation, with both umbones projecting slightly dorsally of the hingeline. Primary ribs strong, rather broad, rounded, closely set, and number 30-36; secondary ribs much weaker and posteroventrally inserted late in some interspaces. Postumbonal length about 1.5-2.5 times preumbonal length. Posterior ear about one-half posterior length, ribbing on ear not always visible.

Remarks.-Alaskan specimens of this species were first recorded from North America by Grant-Mackie and Silberling (1990) who pointed out that they cannot be separated from the typical Asian examples by any significant feature. They were placed in the subgenus Eomonotis because the unexcavated, poorly separated posterior ear clearly bears radial ribs at least on some specimens, although the ears of some internal casts appear smooth. M. (Eo.) anjuensis differs from $M$. (Eo.) typica and pinensis in its coarser ribbing and more nearly transverse outline, which is notably longer than high. From M. (Eo.) inaequivalvis and similar forms, it differs both in these same features and in its less inflated left valve; it differs from M. (Eo.) daonellaeformis by its higher primary rib count and by the shape of the anterior margin that does not project above the hingeline. It is closest to M. (Eo.) obtusicostata but has better formed, more numerous primary ribs and a more transverse outline.

\section{MONOTIS (EOMONOTIS) n. sp. aff. M. (EO.) ANJUENSIS Bytschkov and Efimova, 1966 \\ Plate 11, figures 17-18}

Diagnosis.-Medium-size M. (Eomonotis) up to 50 $\mathrm{mm}$ long, obliquely oval, subequivalved, and of low inflation. About 20 broad, rounded, primary ribs; weaker secondary ribs inserted early in most interspaces, and faint tertiary ribs near the margin in the posteroventral quadrant.

Remarks.-This form, known from only one locality, shows many similarities to $M$. (Eo.) typica in outline, size, and ribbing, but the primary ribs are much more prominent and the ribbing better differentiated. It is much closer to $M$. (Eo.) anjuensis, especially in rib form, but it has fewer primary ribs, and the secondary ribs appear earlier. From $M$. (Eo.) obtusicostata it is separable by these same characters.

\section{MONOTIS (EOMONOTIS) DAONELLAEFORMIS Kiparisova, 1960} Plate 6, figures 1-5

Diagnosis.-Medium size (up to $40 \mathrm{~mm}$ long). Shape transversely oval, with anterodorsal margin projecting 
dorsally above the projection of the hingeline. Beaks inconspicuous and valves of subequal, low inflation. Postumbonal length 1.5-2.0 times preumbonal length. Sculpture of about 30 prominent, rounded, primary radial ribs; secondary ribs much weaker, inserted at about half valve height. Anterior ribs, and sometimes also posterior ribs, curve dorsally.

Remarks. - This species is characterized by its transversely oval outline, dorsally projected anterodorsal margin, and moderately broad, rounded, primary ribs that, however, are narrower than those of $M$. obtusicostata. Westermann (1966) identified $M$. cf. daonellaeformis from the Canadian Arctic, but the specimens to which he refers are not readily related to this species because of their sparse ribbing and greater left-valve inflation.

\section{MONOTIS (EOMONOTIS) n. sp. aff. M. (EO.) INAEOUIVALVIS Bronn, 1930}

Plate 10, figure 5

Remarks. - This unique form is represented by a single small (25 mm long), obliquely oval, well-inflated ( $8 \mathrm{~mm}$ in width) left valve having closely spaced, fine ribs of equal strength, differentiated only by their level of origin. Forty primary ribs commence near the beak, and eight secondary ribs are then inserted in the ventral quadrant at mid height. The posterior ear is finely ribbed, set off by a distinct posterior sinus, and about $1 / 3$ the posterior length of the shell, which is about $2 \frac{1}{2}$ the anterior length.

This shell is especially characterized by its high primary rib count and inflation. It is most closely similar to the European $M$. inaequivalvis and $M$. hoernesi Kittl, differing from the former by its greater number of primary and fewer secondary ribs and from the latter by its oval outline, greater inflation, and fewer primary ribs. Westermann (1962) described "Monotis n. sp.? aff. inaequivalvis" from northeastern British Columbia, but his form is distinct from ours in its still greater number of primaries (about 50) and in its more prominent posterior ear.

\section{MONOTIS (EOMONOTIS) JAKUTICA (Teller, 1896)}

Plate 3, figures 16-17; plate 5, figures 7-10; plate 10 , figures ?1-4, ?6, ?10-11

Diagnosis.-Small to medium size (up to $30 \mathrm{~mm}$ long), subcircular to obliquely oval, with left valve strongly inflated and right valve almost flat. Beak situated at about the anterior third of the valve length. Sculpture of $18 \pm 4$ strong, high, sharp, well-spaced primary ribs, much weaker secondary ribs inserted early, and in some specimens very weak tertiary ribs inserted marginally in a few interspaces. Posterior ear bears $2-5$ fine ribs and is $1 / 2-1 / 3$ of posterior valve length.

Remarks. - This species is commonly associated with M. subcircularis in North American collections but has seldom been recorded. The marked inflation of the left valve and the coarser and larger number of primary ribs readily separate $M$. jakutica from juvenile $M$. subcircularis. These same characters separate $M$. (En.) ochotica densistriata from M. subcircularis, but the former differs from $M$. jakutica in having still more delicate ribbing (compare pl. 1, figs. 1-3, with pl. 5, fig. 7) and a smooth posterior ear. The strongly inequivalved shape also clearly differentiates $M$. jakutica from other North American Eomonotis except for $M$. n. sp. aff. M. (Eo.) inaequivalvis that has twice as many and much finer primary ribs.

\section{MONOTIS (EOMONOTIS) OBTUSICOSTATA Westermann, 1966}

Plate 10, figures 7-9, 12-14; plate 11, figures 10-12

Diagnosis.-Medium-size (up to $40 \mathrm{~mm}$ long), obliquely oval, subequivalve, of low inflation, with umbo of the left valve projecting slightly above hingeline. Sculpture of 25-30 broad, rounded, well-spaced, primary ribs, with weak secondary ribs inserted near the ventral margin. Ribs tending to weaken anterodorsally and posterodorsally. Posterior shell length about three times the anterior shell length, which approximately equals the length of the posterior ear.

Remarks. - This species is readily separated from most species of M. (Eomonotis) by its coarser, well differentiated ribbing. It is similar in shape to $M$. (Eo.) anjuensis but differs in having, on the average, fewer ribs and in exhibiting distinct fading of the ribs towards both the anterior and posterior dorsal margins.

\section{MONOTIS (EOMONOTIS) PINENSIS Westermann, 1962}

Plate 1, ?figure 16 ; plate 5 , ?figures $18-22$; plate 6 , ?figures 6-10, 12-16; plate 11, figures ?8-9, 16

Diagnosis.-Medium size (up to $40 \mathrm{~mm}$ long), obliquely oval shells of low inflation. Left-valve umbo prominent, projecting significantly above hingeline; rightvalve umbo much less prominent, barely projecting beyond hinge. Ribs fine, well differentiated, quite well spaced; primary ribs number $30 \pm 6$; secondary ribs inserted in most interspaces, some tertiary ribs inserted marginally. Posterior ear $1 / 2$ to $1 / 3$ posterior length of valve, which is $1.5-2.5$ times the anterior length.

Remarks.-Few Alaskan specimens can be positively assigned to this species, although imperfectly preserved similar and probably conspecific forms are locally common. The diagnosis given above is taken from Westermann's original description and from topotype collections. Monotis (Eo.) pinensis is most closely similar to M. (Eo.) typica but has a slightly more inflated left valve, more primary ribs, better differentiated primary and secondary ribs, and a better separated posterior ear. From other forms of M. (Eomonotis) it is distinguished by its low inflation and (or) fine ribbing.

\section{MONOTIS (EOMONOTIS) TYPICA (Kiparisova, 1936)}

Plate 5, ?figure 5; plate 8, figures ?3-4, 5-8, ?10,

13-17; plate 9, ?figure 7; plate 11, figures $19-20$

Diagnosis.-Medium size (up to $40 \mathrm{~mm}$ long), obliquely oval, with up to 70 fine, closely spaced ribs of two 
orders. Primary ribs number 22-29; secondary ribs of subequal strength. Posterior shell length 2-3 times anterior shell length. Right valve very little inflated, beak not projecting above the hingeline; left valve a little more inflated, the beak projecting slightly dorsal to the hingeline.

Remarks. - This species, originally named by Kiparisova (1936) as a variety of "Pseudomonotis scutiformis" from the basal beds of the Monotis sequence in the Russian Far East, is well represented in Alaska. It is distinguished primarily by the weakly differentiated posterior ear, the posterior sinus being shallow, if perceptible at all, and by the numerous ribs among which the primary and secondary ribs are poorly differentiated.

\section{OCCURRENCE OF MONOTIS IN ALASKA}

The accreted tectonostratigraphic terranes of Alaska and adjacent parts of Canada from which Monotis is known are shown in figure 1 (after Jones and others, 1987; Monger and Berg, 1987). Monotis also occurs in the relatively small area of east-central Alaska, which is interpreted as part of the North American Continent that was not accreted during Phanerozoic time. Numbered localities in figure 1 are either those from which the specimens figured herein were collected or those discussed in the text where other tectonically or paleogeographically significant occurrences of Monotis are known.

\section{NORTHERN ALASKA}

In northern Alaska several different species of Monotis are abundantly represented in Upper Triassic rocks of the North Slope, Endicott Mountains, and DeLong Mountains subterranes of the Arctic Alaska terrane. According to Bodnar (1984), the Monotis-bearing strata are condensed, coldwater, anoxic to hypoxic deposits representing an original northeast-southwest (in present coordinates) progression to deeper, below wave-base, depositional environments. These rocks have been structurally imbricated, with marked stratigraphic juxtaposition at subterrane boundaries, during Early Cretaceous north-verging thrust faulting.

In outcrops of the North Slope subterrane in northeastern Alaska, as at localities 3 and 4 (fig. 1), Monotis occurs in black, sooty shale and concretionary limestone at the top of the Shublik Formation and in the basal meter, or so, of the overlying Karen Creek Sandstone as described by Detterman and others $(1975)^{3}$. Monotis is also well represented in well

\footnotetext{
${ }^{3}$ In the list of fossil collections given by Detterman and others (1975, p. 43) the description of collection number 1 refers to collection number 3 as plotted in their figure 6 , and number 3 in their list refers to number 1 in their figure.
}

cores from equivalent strata in the subsurface of the North Slope, both from the Prudhoe Bay area (on the coastline northwest of loc. 3, fig. 1) and the National Petroleum Reserve (for example, locs. 1 and 2, fig. 1).

In the Endicott Mountains subterrane of the Arctic Alaska terrane (locs. 8, 10-11, fig. 1), Monotis is locally abundant in the limestone member and upper part of the chert member of the Otuk Formation, as described, for example, by Mull and others (1982), ${ }^{4}$ Bodnar (1984), and Blome and others (1988). These two members of the Otuk are the approximate age equivalents of the Shublik Formation in the North Slope subterrane. They are mainly oxygen-deficient, below wave-base marine deposits in which Monotis is associated with few others kinds of fossils besides halobiid bivalves, radiolarians, and conodonts. The depositional setting of the most deep-water parts of the Otuk was interpreted by Bodnar (1984) as "an outer shelf, a very low-angle slope, or *** an epicontinental sea on a broad continental basement in up to inner bathyal water depths." In the Point Hope-Lisburne Hills region at the western end of northern Alaska (locs. 5, 6, fig. 1), the rocks containing Monotis are also assigned to the Otuk Formation, but the underlying Paleozoic section has stratigraphic characteristics transitional between the Endicott Mountains and North Slope subterranes. Farther east in the structurally complex Brooks Range, some Otuk Formation localities, such as locality 9 (fig. 1), may be within the still more offshore upper Paleozoic and Triassic rocks of the structurally higher DeLong Mountains subterrane.

Monotis faunas in the various subterranes of the Arctic Alaska terrane include most of the same species and subspecies and have about the same diversity. Specimens either definitely or provisionally assignable to Monotis (Entomonotis) ochotica ochotica, M. (Pacimonotis) subcircularis, M. (Eomonotis) pinensis, M. (Eo.) obtusicostata, and M. (Eo.) typica locally occur in profusion. However, despite their abundance, well-preserved specimens and unbroken biostratigraphic sequences are relatively few, due to the prevalent intense, fold-and-thrust style of deformation and the general lack of good exposure. Monotis (Entomonotis) pachypleura is well represented only in the westernmost Otuk Formation exposures. The Monotis-bearing sequence in these exposures may preserve younger beds whose age equivalents are cut out disconformably at the top of the limestone member farther east in the Otuk Formation and at or just above the top of the Shublik Formation of northeast Alaska where either $M$. (P.) subcircularis (or the closely similar M. (M.) haueri) or M. (Entomonotis) ochotica ochotica are the youngest Monotis and occur, at most, a few meters above middle Norian species of Eomonotis.

\footnotetext{
${ }^{4}$ Note that the subgeneric names Eomonotis and Entomonotis are applied partly to the wrong species on p. 360 of Mull and others (1982).
} 
The occurrence of another common fossil, the Ladinian flat clam Daonella frami, in the basal part of the Shublik and near the boundary between the limestone and shale members of the Otuk, poses a pitfall for geologists studying these condensed, highly deformed, imperfectly exposed strata that commonly crop out as partial overturned sections. The pattern and strength of ribbing of $D$. frami are remarkably similar in negative impressions to that in positive impressions of species of Monotis, such as M. subcircularis, that bear ribs of distinctly different orders, and vice versa. The two different kinds of bivalves have on occasion been confused on the basis of fragmentary, poorly preserved material. As a consequence, the younger and older parts of Triassic sections sometimes have been mistaken for one another (Patton and Tailleur, 1964).

\section{EAST-CENTRAL ALASKA}

Monotis-bearing rocks on and near the Yukon River in Alaska (locs. 13, 14, fig. 1), near the Canadian border, are part of a condensed Middle and Upper Triassic sequence of dark, bituminous shale and impure limestone that may be less than $100 \mathrm{~m}$ in total thickness and forms the base of the Glenn Shale (Brabb, 1969). Because of the recessive nature and local structural complexity of these rocks, complete sections through even the relatively thin Monotis-rich part of the sequence are not exposed. Isolated, lithologically and faunally similar strata crop out in a few places in the Mackenzie fold belt $100-400 \mathrm{~km}$ to the east in Canada (Mountjoy, 1967). These rocks, in turn, are similar to the Late Triassic continental-slope deposits that are well represented in the Northern Rocky Mountains thrust belt of northeastern British Columbia. Other parts of the pre-Tertiary section also show transitions from the intricately thrust-faulted exposures near the Alaska-Canada border eastward into the North American Shelf. Hence, the east-central Alaskan occurrences of Monotis are regarded as belonging to a tectonically disrupted continuation of the continental margin and not to an accretionary terrane.

In the east-central Alaskan strata, Monotis shells are commonly so abundantly stacked together that compression has impressed one shell into another forming a confused pattern of interfering ribbing and incomplete shell outlines (pl. 6, fig. 13; pl. 7, figs 1-2). The abundance of shells themselves makes it difficult to obtain positively identifiable specimens. Species of Eomonotis, such as M. (Eo.) daonellaeformis (listed by Silberling as M. "scutiformis typica" in Brabb, 1969, p. 112) and probably M. (Eo.) pinensis, are particularly well represented. In younger beds, specimens that probably belong to $M$. (P.) subcircularis are well represented, although invariably poorly preserved. Other late Norian species are not known, most likely because of lack of exposure.

\section{CENTRAL AND SOUTHERN ALASKA}

Monotis has been collected from several different terranes in the Kuskokwim Mountains, Alaska Range, and Wrangell Mountains of central and southern Alaska. These terranes lie both north and south of the Denali fault (fig. 1), a major strike-slip fault that in this part of Alaska follows a Mesozoic suture zone (Nokleberg and others, 1985).

Occurrences of Monotis-bearing rocks north of the Denali fault in central Alaska are very limited. In the areally extensive Nixon Fork terrane, Triassic strata, along with Permian rocks, have been found only in one small area (loc. 15, fig. 1). Pre-Cretaceous rocks forming the major share of the Nixon Fork terrane are Ordovician through Devonian shelf carbonate rocks inferred to overlie Precambrian metasedimentary rocks. The total thickness of dated Triassic rocks, all of which are apparently Upper Triassic, is estimated by Patton and others (1977) to be about $60 \mathrm{~m}$. Gradationally above these are another $100 \mathrm{~m}$ of bedded chert that is latest Late Triassic and possibly Jurassic in age. In the Upper Triassic sequence beneath the chert, Monotis occurs at several different levels within 5-10 m of incompletely exposed, platy weathering, silty or finely sandy, phosphatic, spicular limestone (pl. 5). Thicker and more massive interbeds within and just above the fossiliferous part of the sequence are impure bioclastic packstones and grainstones, formed largely of brachiopod, mollusk, and echinoderm fragments, and intraclastic sedimentary breccias containing abundant dark clasts of partly dolomitized phosphatic rock. These massive beds are interpreted as debris-flow deposits within a deep-water sequence The only megafossils preserved are pelagic forms, such as Halobia, Monotis, and the enigmatic, spherical, planktonic(?) hydrozoan Heterastridium. The fossiliferous part of the section grades upward though a few tens of meters of notably spiculitic impure limestone into the bedded chert unit.

At one of the two fossiliferous exposures, M. (Eomonotis) jakutica and at least one other kind of Eomonotis occur in float from USGS Mesozoic loc. D11286 about 4-5 m below M. (Pacimonotis) subcircularis from USGS Mesozoic locality D11285; at the other exposure (USGS Mesozoic loc. D11286), about $3 \mathrm{~km}$ away, M. (Eomonotis) anjuensis occurs in bedrock several meters below $M$. (P.) subcircularis and Heterastridium. The occurrence here of the spherical hydrozoan Heterastridium is noteworthy because of its possible biogeographic significance; this is its northernmost known occurrence in North America.

Southeast of the Nixon Fork terrane, and only about 2 $\mathrm{km}$ north of the Denali fault at locality 16 (fig. 1), Monotis has been found in one place within the McKinley terrane (pl. 5, figs. 17-22). Here, Monotis provisionally assigned to $M$. (Eomonotis) pinensis is abundant along with Halobia cf. $H$. fallax in a slab of black, laminated limestone, about 0.1 by $1.0 \mathrm{~m}$ in cross section, within Upper Jurassic(?) to Cretaceous flysch. This slab was found at an Early Cretaceous 
Inoceramus and belemnoid locality (map locality no. 4 of Reed and Nelson, 1977) and is best interpreted as an olistolith within the flysch. Other known Triassic rocks elsewhere in the structurally composite McKinley terrane are radiolarian cherts and pillow basalt and related mafic intrusive rocks.

Farther east and on the south side of the Denali fault Monotis is known from the Chulitna, Susitna, Nenana, and Wrangellia terranes. In the Chulitna terrane poorly preserved Monotis, questionably identified as $M$. (P.) subcircularis (pl. 4, figs. 9-10), occurs at locality 17 (fig. 1), which is map locality 34 of Reed and Nelson (1977). This is the only occurrence known in the Chulitna terrane. The ageequivalent strata farther to the northeast in the terrane probably represent a more shallow-water facies (Jones and others, 1980).

In the Susitna terrane Monotis is more abundant but known only from float collections at locality 18 (fig. 1). Consequently, although both Monotis ( $P$.) ?subcircularis and $M$. (M.) alaskana are represented (pl. 4, figs. 6-8), their relative stratigraphic position is unknown. The entire Susitna terrane is a huge recumbent fold of pillow basalt and intercalated volcaniclastic sedimentary rocks tectonically enclosed in deformed Upper Jurassic and Cretaceous flysch of the Kahiltna terrane. The Nenana terrane occurs nearby, also in fault contact with Upper Jurassic and Cretaceous flysch. It consists, however, mainly of metamorphosed impure limestone and calcareous sandstone in which poorly preserved Monotis that resemble $M$. (P.) subcircularis have been found at one place (loc. 22, fig. 1).

In the Wrangellia terrane Monotis occurs at many localities in the McCarthy Formation, typical exposures of which are in the southern Wrangell Mountains (MacKevett, 1978) near locality 19 (fig. 1), but which is known as far west as locality 23 (fig. 1), on the south flank of the Alaska Range (Silberling and others, 1981). In its lower part, which is latest Triassic and Early Jurassic(?) in age, the McCarthy Formation is regularly interbedded calcareous carbonaceous shale, impure limestone, and impure spiculitic chert (MacKevett, 1970). These deep-marine rocks were deposited after the huge plateau of Triassic oceanic basalt that distinguishes Wrangellia foundered during Late Triassic time.

Pervasive minor structures make stratigraphic measurements within the McCarthy Formation inaccurate, but Monotis (pls. 3-4) occurs at various levels through at least $60 \mathrm{~m}$ of section. The stratigraphically lowest occurrences of Monotis are generally $50-100 \mathrm{~m}$ above the base of the McCarthy and are characterized by a profusion of $M$. (P.) subcircularis, with which a few specimens of $M$. (Eomonotis) jakutica are sometimes associated. In the few places where its occurrence has been observed in bedrock, $M$. (M.) alaskana invariably is stratigraphically above $M$. (P.) subcircularis.

Monotis (M.) alaskana has its type locality (USGS Mesozoic loc. 9961) in the McCarthy Formation of the Wrangellia terrane about $40 \mathrm{~km}$ west of the area in the
Wrangell Mountains from which the specimens illustrated herein were collected. This species from the Wrangell Mountains was regarded as a synonym of $M$. (M.) salinaria by Silberling (as in MacKevett, 1970; Silberling and others, 1981) but, as explained previously, it is now regarded as being distinct. The more coarsely ribbed specimens figured as $M$. (M.) ?haueri (pl. 3, figs. 8-13) are the only ones of this morphology from a measured section and occur $18 \mathrm{~m}$ above M. (M.) alaskana.

\section{SOUTHWESTERN ALASKA}

In the Kuskokwim region of southwestern Alaska, small lots of Monotis have been collected during the course of geologic investigations from several different localities, four of which are plotted as localities 25-28 in figure 1. Of these, localities 26 (USGS Mesozoic locs. M12909 and M18927) and 27 (USGS Mesozoic locs. 23170 and M6671) represent the Togiak and Goodnews terranes, respectively, whereas the terrane assignments of localities 25 and 28 are less certain. The Togiak terrane is interpreted by Box (1985) as a Late Triassic to Early Cretaceous intraoceanic volcanic arc, against and beneath whose northwestern margin (in present-day coordinates) the Goodnews terrane was structurally emplaced as a subduction complex. Locality 25 is from an isolated exposure along the Kuskokwim River (USGS Mesozoic loc. M1879) that might be an outlier representing older strata of the Nyac terrane. The Nyac is another belt of intraoceanic arc rocks from which Middle Jurassic fossils are known. Original continuity along strike of the Nyac and Togiak terranes prior to large-scale Cenozoic strike-slip faulting is suggested by Box (1985). Locality 28 (USGS Mesozoic locs. 17080 and D10708) is along the boundary between the Togiak and Tikchik terranes. It is in rocks that probably represent the older parts of the Togiak terrane, the underlying Tikchik terrane being either part of a subduction complex structurally below the Togiak or perhaps even part of the original depositional substrate of the Togiak. Thus, the Monotis occurrences in southwestern Alaska are probably representative of a single, major, heterogeneous Mesozoic intraoceanic arc and its accretionary subduction complex, all of which were amalgamated by Early Cretaceous time (Box, 1985). Most of the meager and poorly preserved Monotis faunas in collections from these rocks, at least provisionally, can be assigned to the ubiquitous $M$. $(P$.) subcircularis, along with a few specimens apparently having the morphology of $M$. (En.) o. densistriata and M. (M.) haueri. As explained previously, the morphometric limits of these two species may include, respectively, inflated immature and densely ribbed variants of $M$. (P.) subcircularis. One Monotis collection (USGS Mesozoic loc. M6671) from the belt of outcrops represented by locality 27 (fig. 1) deserves special attention, however, because it contains only conspicuously inflated, small- to medium-size shells, preserved as fragmentary molds. In the absence of associated 
fragments of large, $M$. (P.) subcircularis-like shells, this occurrence may represent a population assignable to a midor high-paleolatitude representative of $M$. (Entomonotis), such as M. (En.) ochotica, its ribbing being coarser than that of the paleolatitudinally ambiguous $M$. (En.) densistriata.

In the Peninsular terrane, Monotis is especially well represented from a number of localities in the vicinity of Cape Kekurnoi (loc. 21, fig. 1) on the east side of the Alaska Peninsula (pl. 2). It also has been collected farther north in the Peninsular terrane on either side of the mouth of Cook Inlet, collections from the east side of the inlet having been obtained from Port Graham (loc. 29, fig. 1).

At locality 21, in wave-cut exposures along the shores of Puale and Alinchak Bays, on either side of Cape Kekurnoi, several hundred meters of Upper Triassic, well-bedded, dense limestone, shale, and minor volcaniclastic rocks (the "bedded cherts" lithofacies of Wang and others, 1988) overlie platform-carbonate and volcanic rocks, all of which are late Norian in age. Monotis $(P$.) subcircularis is well represented in collections from relatively low in the well-bedded sequence, however, M. (M.) alaskana occurs near its top. Although the section is disturbed by faults and folds, Detterman and others (in press) reported a minimum stratigraphic separation of about $75 \mathrm{~m}$ between these two species in an unbroken partial section in Alinchak Bay.

Monotis (P.) subcircularis and M. (M.) alaskana are also represented in different collections (for example, respectively, USGS Mesozoic loc. 7234 and 10546) from dense, black carbonaceous limestone of the Peninsular terrane from Port Graham (loc. 29, fig. 1). Stratigraphic relationships of the collections from this area are not known, but in rocks of the same character as those in which the late Norian fossils occur, the characteristic middle Norian flat clams Halobia lineata and $H$. dilitata occur in separate collections (respectively, USGS Mesozoic locs. 6380 and 6382) as does the late middle Norian ammonite Steinmannites (from USGS Mesozoic loc. D13388). Thus, unlike the Peninsular terrane at locality 21 (fig. 1), where the evenly bedded pelagic strata containing flat clams are entirely late Norian, strata of this kind are of both middle Norian and late Norian age at locality 29. This is significant because, although $M$. (M.) alaskana is nowhere known in stratigraphic sequence with any of the characteristically middle Norian species of $M$. (Eomonotis), at most localities, if present at all, middle Norian strata are of different facies than the Monotis-bearing upper Norian strata. At Port Graham, where late Norian M. (M.) alaskana occurs, middle Norian strata of the flat clam-ammonite facies are apparently well represented, and yet Monotis is not found within them.

\section{SOUTHEASTERN ALASKA}

Monotis occurs in the Alexander terrane at localities in Keku Strait (Muffler, 1967) (loc. 20, fig. 1) between Kuiu and Kupreanof Islands, and farther to the north on Admiralty
Island. In Keku Strait, M. (P.) subcircularis is represented in collections from the Hound Island Volcanics on either side of the strait; on the west side it occurs in a remarkably fossiliferous bed of partly silicified marl about $1 \mathrm{~m}$ thick (USGS Mesozoic loc. M1912). In this bed, this species is associated with $M$. (En). cf. M. (En.) ochotica densistriata (pl. 1), which, as explained previously, might be no more than inflated immature variants of $M$. (P.) subcircularis. Additionally, from this same bed there are as many as 50 other kinds of marine invertebrates, mostly bivalves. Among the bivalves is Septocardia cf. S. pascoensis, previously reported only from Peru (Newton, 1983). From other localities on the islands within Keku Strait, the subgenus Eomonotis occurs sparsely with middle Norian halobias, as for example at USGS loc. M1900 where M. (Eo.) ?pinensis occurs with Halobia cf. H. fallax (pl. 1, figs. 15-16). As explained below, M. (Eomonotis) generally indicates middle to high paleolatitudes; thus, the paleobiogeographic interpretation is in agreement with the original paleomagnetic results from the Hound Island Volcanics by Hillhouse and Grommé (1980) who found the paleolatitude of these volcanic rocks of the Alexander terrane to be not significantly different from that of the adjacent margin of cratonic North America. This fits the biogeographic data, because the present-day latitude of Keku Strait is approximately that of the Peace River Foothills of British Columbia, the southernmost occurrence of $M$. (Eo.) pinensis on the craton. To circumvent the platemotion traffic-pattern problem of having an early Mesozoic mid-latitude Alexander terrane parked outboard of relatively low-latitude early Mesozoic terranes, such as Stikinia, the possibility of a southern, rather than northern, paleolatitude for the Alexander terrane was suggested (Newton, 1983; Panuska and Stone, 1985; Silberling, 1985).

Subsequent studies contradict these original interpretations regarding the paleolatitude of the Alexander terrane. First, according to Gardner and others (1988), a Pennsylvanian granitic complex, which is extensive within the Alexander terrane, crosscuts the contact between the Alexander and Wrangellia terranes in southern Alaska near the International Border. This implies that the two terranes have travelled together at least since the Pennsylvanian. As the Triassic paleolatitude of Wrangellia is well established in the range of $10^{\circ}-17^{\circ}$ (Hillhouse and Grommé, 1984), that of an adjoined part of the Alexander terrane should also be low. Second, restudy of the paleomagnetism of the Hound Island Volcanics by Haeussler and Coe (1992) indicates that the magnetic direction originally reported by Hillhouse and Grommé (1980) was a fortuitously realistic combination of two magnetic overprint directions and that the primary component of magnetization in these rocks yields a paleolatitude of $19.2^{\circ} \pm 10.3^{\circ}$, in much better agreement with the paleolatitude of Wrangellia. A reappraisal of all the collections of fossils from Triassic rocks of the Alexander terrane also yields some biogeographic support for this current viewpoint. For example, a fairly diverse late Norian shelly fauna 
from Gravina Island near the southern terminus of the Alexander terrane, about $225 \mathrm{~km}$ south-southeast of locality 20 (fig. 1), is most similar to paleoequatorial faunas from the Methow-Tyaughton terrane of southern British Columbia and of the Gabbs Formation of the Paradise terrane in western Nevada (N.J. Silberling, unpub. data). Among several collections of Monotis (M.) subcircularis from Mole Harbor, in the Alexander terrane on the east side of Admiralty Island about $90 \mathrm{~km}$ north of locality 20 (fig. 1), one collection (USGS Mesozoic loc. 10168) can be assigned to $M$. (M.) alaskana, a Monotis species typical of Wrangellia and a biogeographic hallmark of low paleolatitudes.

Both mid- and low-paleolatitude biogeographic indices, thus, occur among the faunas of the Alexander terrane. They are, however, from different exposures than those that yielded the current understanding of the original component of paleomagnetism in the Hound Island Volcanics (Haessler and Coe, 1992) in the vicinity of Keku Strait and those from which shells of fossils of apparent South American affinity were collected. Structural deformation of the Triassic rocks in this area is intense enough to support suspicion that different facies are juxtaposed on as yet unrecognized faults. However, the amount of post-Triassic tectonic juxtaposition within Keku Strait itself is limited, because the boundary of major juxtaposition of Paleozoic facies that passes through Keku Strait and that separates the Craig and Admiralty subterranes of the Alexander terrane, is overlapped by the Pybus Formation of Permian age (Berg and others, 1978).

In an attempt to rationalize all the current geologic and paleontologic data from the Alexander terrane, it can be pointed out that the terrane, as presently configured, subtends about $10^{\circ}$ of latitude. Moreover, post-Triassic structural disruption within the Alexander terrane could have been sufficient to have imbricated or telescoped an even greater original latitudinal span. Thus, paleolatitudes approximating a $15^{\circ}-30^{\circ}$ range within Alexander terrane rocks might be permissible and would satisfy the paleolatitudinal perceptions based on the relevant Monotis faunas. In view of the right-slip Mesozoic and Cenozoic history on major faults that are subparallel to this part of the Pacific margin and the relatively outboard position within the Alexander terrane of Keku Strait, location of the Alexander terrane in relatively low latitudes of the southern hemisphere during the Late Triassic is still an attractive hypothesis.

\section{AGE AND BIOSTRATIGRAPHY OF ALASKAN MONOTIS FAUNAS}

Monotis-bearing strata are broadly correlated with the middle and upper Norian Stage of the Upper Triassic (for example, Tozer, 1980). In more recent studies (GrantMackie, 1986; Grant-Mackie and Silberling, 1990), beds containing species of $M$. (Eomonotis) are mainly correlated with the Columbianus Zone, the ammonite zone that forms the upper part of the middle Norian. Beds containing species of the subgenera M. (Monotis), M. (Pacimonotis), and M. (Entomonotis) are correlated with the Cordilleranus Zone that defines the lower part of the upper Norian. Monotis (Eo.) jakutica is the only one of the known Alaskan species of the subgenus Eomonotis that occurs in the upper Norian Cordilleranus Zone. In Alaska and elsewhere, there is no compelling evidence that any Monotis species appears either in strata below the Columbianus Zone or higher than the Cordilleranus Zone (Tozer, 1980).

Aside from the occasional occurrence of ammonoids in Monotis-bearing strata of Alaska, other kinds of marine megafossils associated with Monotis are mainly restricted to the morphologically distinct flat clam Halobia and the enigmatic hydrozoan Heterastridium. Halobia, various species of which are characteristic of Karnian through middle Norian strata, co-occurs with different species of $M$. (Eomonotis) at a number of places in Alaska, commonly on the same bedding surfaces. It is found, for example, with $M$. (Eo.) daonellaeformis in the Upper Yukon, with M. (Eo.) typica in the Endicott Mountains and North Slope subterranes, with $M$. (Eo.) obtusicostata and M. (Eo.) ?jakutica in the North Slope subterrane, and with possible or probable $M$. (Eo.) pinensis in the North Slope subterrane and the Alexander and McKinley terranes. All these occurrences are in the late middle Norian; nowhere in North America is Halobia known to extend stratigraphically above the Columbianus Zone.

Heterastridium, the other common associate of Monotis, was evidently a planktonic organism that is locally abundant in the Nixon Fork, Togiak(?), Peninsular, Wrangellia, and Alexander terranes. These enigmatic fossils are spherical, unless compacted into oblate-spheroids, commonly from 10 to more than $50 \mathrm{~mm}$ in diameter, contain a delicate, radial, cellular interior meshwork, and have a distinctive outer surface, densely covered by low, isolated papillae. Heterastridium is known only from the Cordilleranus Zone in North America, but elsewhere in the world it has been reported from older Norian strata.

Although much of the present understanding of the biostratigraphic distribution of Monotis is based on Alaskan successions (in addition to those in Canada, Far Eastern Russia, Japan, and New Zealand), there are few welldocumented, stratigraphically unbroken Alaskan sections from which the sequential relations among the various species can be established. The most informative sequential data from Alaskan occurrences of Monotis (in terms of USGS Mesozoic localities) are as follows:

(1) In the Upper Yukon, M. (Eo. daonellaeformis (loc. M1714; pl. 6, figs. 1-5) occurs 3-10 m below $M$. (Eo.) ?pinensis (loc. M1715; pl. 6, figs. 6-16). This is the only unquestioned occurrence of $M$. (Eo.) daonellaeformis in Alaska, but in northeastern Asia, Dagys and others (1979) define a M. daonellaeformis 
subzone of the "M. scutiformis zone," overlain by a M. pinensis subzone.

(2) In the Simpson No. 1 test well in the North Slope subterrane, M. (Eo.) typica (as figured on plate 11) occurs in the core segment from 6,300-6,306 ft, above the occurrence of $M$. (Eo.) pinensis in the core segment at 6,307-6,318 ft. This is the reverse of the stratigraphic order reported from Far Eastern Russia by Arkhipov (1970).

(3) In the eastern part of the North Slope subterrane from the surface reference section of the Shublik Formation and the overlying Karen Creek Sandstone at Fire Creek, three of the Monotis species figured on plate 11 occur in sequence. Here, M. (En.) ochotica, sensu stricto, in the basal part of the Karen Creek, overlies $M$. cf. $M$. (Eo.) pinensis, which is underlain about $10 \mathrm{~m}$ lower by $M$. (Eo.) obtusicostata.

(4) One of the most complete successions of different kinds of Monotis was collected by I.L. Tailleur (U.S. Geological Survey) from the almost completely exposed, subvertical, condensed section of the Otuk Formation along the Kukpuk River at loc. M2156 in a Triassic section like that of the Endicott Mountains subterrane. As measured from highest to lowest, beneath the apparent top of the Otuk, the following forms are represented:

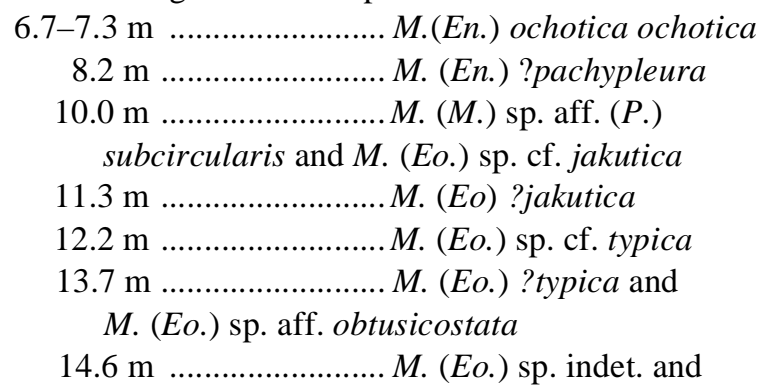

Halobia sp. indet.

Unfortunately, most of these collections are not well preserved, so most identifications are uncertain, but sequential relations of the various forms accord well with those found elsewhere.

(5) Monotis (Eo.) obtusicostata was originally described by Westermann (1966) from British Columbia in association with $M$. (Eo.) pinensis. Specimens provisionally referred to $M$. (Eo.) obtusicostata (Dutro and Silberling, 1988, pl. 30.1, figs. 6-7) and $M$. (Eo.) pinensis (pl. 6, fig. 12-16), respectively from the North Slope subterrane and the Upper Yukon region, are on the same bedding surfaces with the ammonite Neohimavatites cf. N. canadensis (McLearn), which is indicative of the uppermost of the three subzones established by Tozer (1980) within the Columbianus Zone.

(6) In the Nixon Fork terrane, M. (Eo.) anjuensis (pl. 5) was collected from a single bed (loc. D11286), stratigraphically above which $M$. (P.) subcircularis was collected in float. At another nearby section, float specimens in different slabs of questionable M. (Eo.) typica and M. (Eo.) jakutica occur 4-5 m below the occurrence of $M$. (P.) subcircularis in bedrock.

(7) Monotis (En.) ochotica (sensu stricto) occurs 2.4 to 4.6 $\mathrm{m}$ above $M$. (P.) subcircularis at locs. M2650 through M2652 from Fire Creek in the North Slope subterrane in collections other than those containing the specimens figured on plate 11 . This superposition is probably also true in the Endicott Mountains subterrane, as noted in (4). In northeastern Asia, however, M. (En.) ochotica apparently occurs earlier, immediately above beds containing M. (Eo.) pinensis and M. (Eo.) scutiformis, and characterizes the younger of two Monotis zones recognized there (Dagys and others, 1979; Arkhipov and Truschelev, 1982; Bychkov and Polubotko, 1984). This may explain the apparent occurrence of $M$. (En.) ochotica below M. cf. $M$. (P.) subcircularis in the West Dease No. 1 well, North Slope terrane (pl. 11, figs. 13-15). In British Columbia, these two species are reported by Westermann and Verma (1967) to occur together. Nowhere is $M$. (En.) ochotica found in sequence with M. (M.) alaskana.

(8) Monotis (Eo.) jakutica is known from Wrangellia, in association with $M$. (P.) subcircularis (pl. 3, figs. 16-20), from the Nixon Fork terrane with $M$. (Eo.) ?typica (pl. 5, figs. 5-10), and possibly from the North Slope subterrane with $M$. (Eo.) obtusicostata (pl. 10, figs. 7-12). Near Point Hope, M. (Eo.) jakutica occurs with poorly preserved, but probable, M. (P.) subcircularis at locs. M2546 and M2541 in the Otuk Formation; from the same general area, it occurs with definite $M$. (P.) subcircularis at loc. M2545; and in British Columbia these two species are recorded together by Westermann and Verma (1967). Various authors (for example, Arkhipov and Truschelev, 1982) have stated that in northeastern Asia M. jakutica is found through a sequence having $M$. (Eo.) scutiformis in its lower part and M. (En.) ochotica (s.s.), M. (En.)o. densistriata, M. (En.) pachypleura, and M. (P.) subcircularis in its upper part. Thus, M. (Eo.) jakutica apparently ranges through a greater part of the Monotis sequence than most other species, and it occurs in both the Columbianus and Cordilleranus ammonite zones; however, in Alaska it is most commonly found in strata containing $M$. $(P$.) subcircularis.

(9) Monotis (En.) ochotica densistriata has been recorded from British Columbia in association with $M$. $(P$.) subcircularis (for example, by Westermann and Verma, 1967), and specimens similar to this 
subspecies (pl. 1, figs. 1-3, 11-12) occur with definite $M .(P$.$) subcircularis in the Alexander terrane.$ In parts of Asia this subspecies is taken to be characteristic of the lower part of the range of $M$. (Entomonotis). For example, (1) it characterizes the Densistriata zone of Nakazawa (1964) in this stratigraphic position in Japan; (2) along with $M$. zabaikalica and M. (Eo.) jakutica, it characterizes the Zabaikalica subzone of Dagys and others (1979), which forms the lower part of their Ochotica zone in eastern Russia; and (3) again in eastern Russia, it is reported by Arkhipov and Truschelev (1982) as characteristic of beds containing $M$. (En.) ochotica below those with $M$. (P.) subcircularis.

(10) Monotis (En.) pachypleura occurs in isolated collections from the more western exposures of the Endicott Mountains subterrane. In addition to the occurrences figured on plate 9, at loc. M2157, in another nearby section of the Otuk Formation, it occurs $1.8 \mathrm{~m}$ above beds with fragmentary Monotis identified as $M$. sp. aff. (P.) subcircularis and $M$. cf. (Eo.) jakutica, and $0.9 \mathrm{~m}$ below strata with $M$. (En.) ochotica (s.s.). At this locality M. (En.) pachypleura is associated with fragments of a large indeterminate Monotis having coarse, rounded ribs, such as those of M. (En.) ochotica.

(11) Monotis (M.) alaskana occurs exclusively at a higher level than $M$. (P.) subcircularis in both the Peninsular and Wrangellia terranes, as illustrated by the examples figured on plates 2 and 3. The other species of M. (Monotis) in Alaska, M. (M.) haueri, is probably represented by specimens (pl. 3, figs. 8-13) still higher in the Wrangellia-terrane section, above the occurrence of $M$. (M.) alaskana. M. (M.) haueri as identified from other terranes may be appreciably older and an associate, perhaps even a variant of $M$. (P.) subcircularis.

Summarizing the itemized relationships, the gross stratigraphic ranges of the various kinds of Monotis known from Alaska are shown in figure 3. Although the actual ranges and the phylogenetic relationships among different forms are far from being established, some generalizations are, nevertheless, possible about the morphologic evolution within the genus. Obvious evolutionary trends are (1) for the posterior ear to lose its ribbed ornamentation and become smooth and more distinctly separated in outline from the rest of the shell; (2) for an increase in maximum relative size; and (3) at least among the earlier forms, for the ribbing to become better differentiated into different orders. Among younger forms, in different lineages there are tendencies towards broader ribs, fading of the ribbing, or both, and towards development of a strongly inflated shape. Despite some overlap in ranges, species of $M$. (Eomonotis) appear first and somehow are ancestral to those of M. (Pacimonotis), M. (Monotis), and M. (Entomonotis); the last two of these subgenera may include the youngest representatives of the genus in North America.

\section{PALEOGEOGRAPHIC SIGNIFICANCE OF ALASKAN MONOTIS FAUNAS}

The known occurrences of the various forms of Monotis in the accreted terranes of Alaska and in the non-accretionary North American rocks in the Upper Yukon region of Alaska are tabulated in figure 4, which shows that different kinds of Monotis occur in Alaskan rocks at different places. The paleogeographic significance of this distribution requires consideration of the paleoecologic constraints on the distribution of these organisms that do not have close morphologic counterparts among modern bivalves. Although not universally accepted (Kauffman, 1988), the widely held view is that most Monotis had a pseudoplanktonic mode of existence, living attached to floating objects, such as sea weeds (for example, Tozer, 1982; Gall, 1983). Evidence for this is (1) the remarkable thinness of their shells compared to their all-over size; (2) their wide distribution in open-marine deposits, apparently without regard to the nature of the substrate; (3) the nature of the inconspicuous anterior ear, which forms a pseudoctenolium indicative of shell attachment to some object by byssal filaments (Grant-Mackie and Silberling, 1990); and (4) the concave-upward preferred orientation of inflated valves of New Zealand examples in pelagic limestones resting on pillow basalts, indicating descent of the shells through the water column unaffected by lateral currents (Silberling and others, 1988). This inferred pseudoplanktonic, near-surface mode of life implies that water temperature, and thus paleolatitude, should be a primary factor in controlling the north-south distribution of different kinds of Monotis.

The unique nature of the Pacific and Arctic margins of North America in displaying a record of the marine Triassic across paleolatitudes ranging from paleoequatorial to moderately high was first discussed by Tozer (1982). Inboard of the Phanerozoic accreted terranes, exposures of cratonbound, or at least craton-related, fossiliferous marine Triassic rocks from western Nevada, the Rocky Mountain Foothills of western Canada, and the Canadian Arctic Islands allow comparisons between, respectively, low, low-middle, and high-middle paleolatitude faunas, including Late Triassic Monotis faunas (Silberling, 1985). Differences among currently cited Norian North American paleomagnetic poles (Haeussler and Coe, 1992; Kent and Witte, 1993), even those from the Colorado Plateau that differ widely from other Norian poles, generally scatter along a trace parallel to the pre-Jurassic North American apparent polar wander path that is roughly normal to the trend of the North American Pacific margin. Thus, paleolatitudes of Norian localities along the cratonic margin are not much affected by these 
differences in pole position that vary as much as $30^{\circ}$ in angular spread. In terms of the revised taxonomic nomenclature used herein, faunal lists compiled from the literature for North American craton-bound Monotis faunas of broadly different paleolatitudes are as follows:

Nevada (low paleolatitude; about $10^{\circ}$ N.)

Monotis (Monotis) alaskana

M. (M.) haueri

M. (Pacimonotis) subcircularis

Northeastern British Columbia (low-middle paleolatitude; about $25^{\circ}-30^{\circ} \mathrm{N}$.)

M. (Eomonotis) callazonensis

M. (Eo.) jakutica

M. (Eo.) obtusicostata

M. (Eo.) pinensis

M. (Eo.) typica

M. (Entomonotis) ochotica s.s.

M. (En.) o. posteroplana

Monotis (Pacimonotis) subcircularis

Canadian Arctic Islands (high-middle paleolatitude; about $50^{\circ} \mathrm{N}$.)

M. (Eomonotis) daonellaeformis

M. (Eo.) jakutica

M. (Eo.) typica

M. (En.) o. posteroplana

Monotis (Pacimonotis) subcircularis

In addition to the implied paleolatitudinal control on the distribution of different forms of Monotis, differences among the faunas from different segments of the cratonic margin could also result from such factors as collection bias and the possibility that strata of appropriate facies and age may not be represented in some regions. However, the mutual exclusion in faunas of different paleolatitudes of $M$. (Monotis) alaskana on the one hand from nearly all species of M. (Eomonotis) and M. (Entomonotis) on the other is regarded as significant. In support of this, in western Nevada the late Norian Monotis (Pacimonotis) subcircularis occurs widely, in places in the same sections containing $M$. $(M$.) alaskana, in the Jungo terrane that is related depositionally to low-latitude cratonic North America (Lupe and Silberling, 1985). In older parts of the Jungo terrane, middle Norian, including late middle Norian, strata are thick and well dated by ammonite and Halobia faunas, and yet no trace of an Eomonotis has ever been found. Similarly, in the northern part of the Stikinia terrane in the southern Yukon, Canada (loc. 24, fig. 1), only M. (P.) subcircularis and $M$. (M.) cf. haueri are known to occur (Westermann, 1966); however, species of $M$. (Entomonotis), such as those that characterize craton-bound late Norian Monotis faunas farther inland at about the same present-day latitude, are unknown. Currently accepted North American Triassic and Jurassic paleomagnetic pole positions place North America at a lower paleolatitude than that previously accepted. Some geologists, for example, Nelson and Mihalynuk (1993), therefore, discount the importance of latitudinal shift of the Stikinia terrane. Still, an appreciable northward displacement of Stikinia with respect to its Triassic record still seems required by the paleobiogeographic relationships. For example, in the same stratigraphic succession as that containing the Monotis faunas at locality 24 (fig. 1) in the Stikinia terrane, one of the

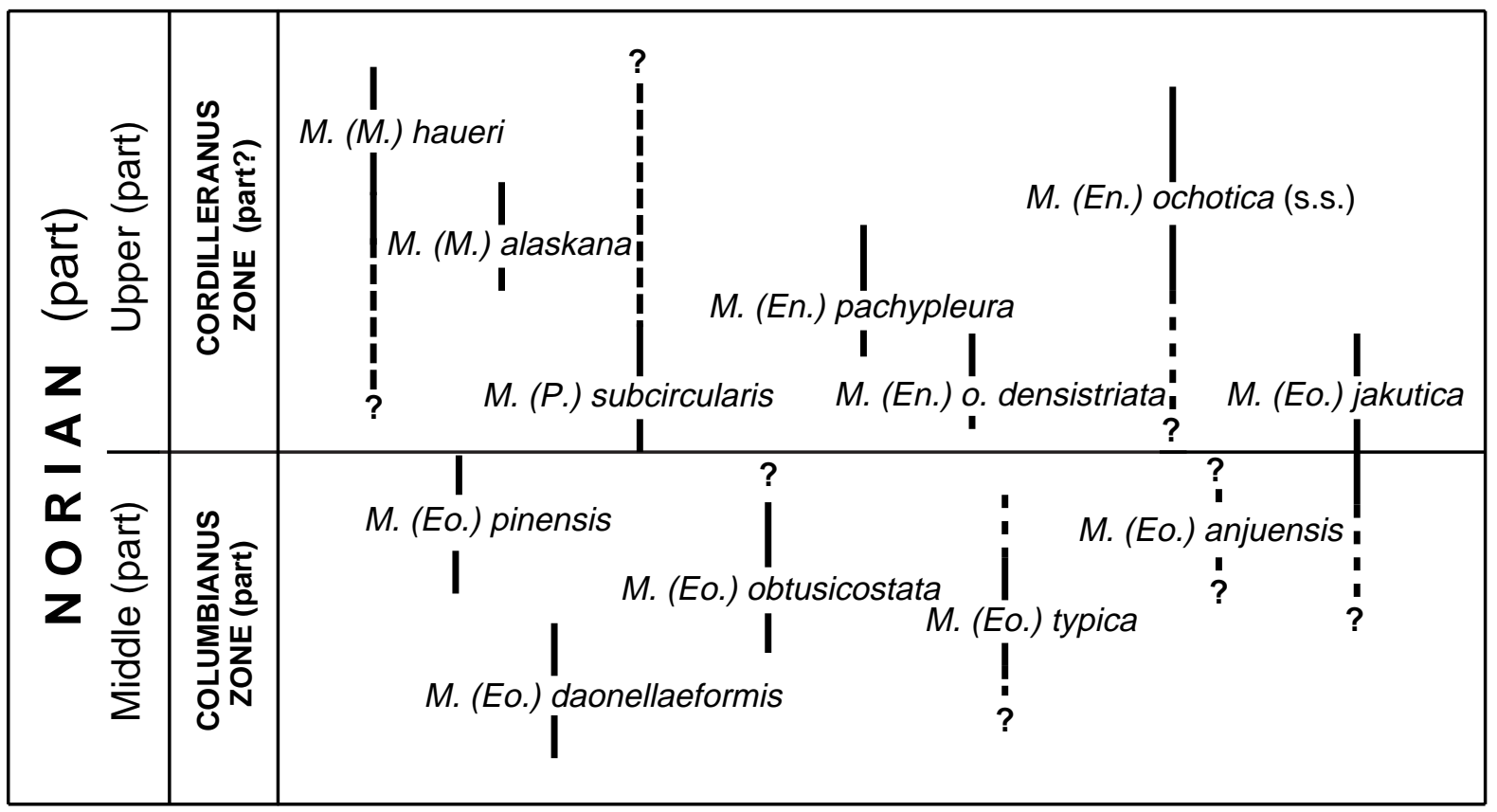

Figure 3. Chart showing the relative stratigraphic ranges of Monotis species and subspecies represented in Alaska. 


\begin{tabular}{|c|c|c|c|c|c|c|c|c|c|c|c|c|}
\hline $\begin{array}{l}\text { TERRANES } \\
\text { (and subterranes) }\end{array}$ & 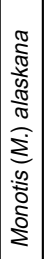 & 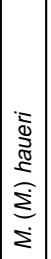 & 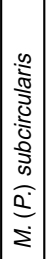 & 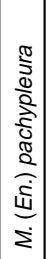 & 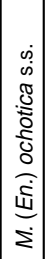 & 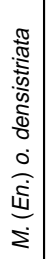 & 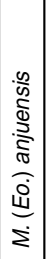 & 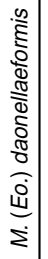 & 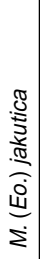 & 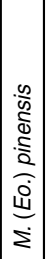 & 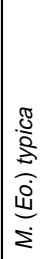 & 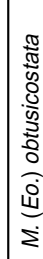 \\
\hline $\begin{array}{l}\text { North Slope } \\
\text { (incl. AAN-AAE) }\end{array}$ & & & $x$ & & $X$ & & aff. & & $\mathbf{X}$ & $\mathbf{X}$ & $\mathbf{X}$ & $\mathbf{X}$ \\
\hline $\begin{array}{l}\text { Endicott Mts. (and } \\
\text { De Long Mts.) }\end{array}$ & & $\mathbf{X}$ & $\mathbf{X}$ & $\mathbf{X}$ & $\mathbf{X}$ & & & & $X$ & & $\mathbf{X}$ & \\
\hline $\begin{array}{l}\text { North America } \\
\text { (Upper Yukon region) }\end{array}$ & & & $x$ & & & & & $\mathbf{X}$ & & $x$ & & \\
\hline Nixon Fork & & & $\mathbf{X}$ & & & & $\mathbf{X}$ & & $\mathbf{X}$ & $x$ & $x$ & \\
\hline McKinley & & & & & & & & & & $x$ & & \\
\hline Goodnews & & & & & $x$ & & & & & & & \\
\hline Nyac? & & $x$ & $x$ & & & & & & & & & \\
\hline Togiak & & $x$ & $x$ & & & $x$ & & & & & & \\
\hline Chulitna & & & $x$ & & & & & & & & & \\
\hline Susitna & $\mathbf{X}$ & & $x$ & & & & & & & & & \\
\hline Nenana & & & $x$ & & & & & & & & & \\
\hline Stikinia & & $x$ & $x$ & & & & & & & & & \\
\hline Wrangellia & $\mathbf{X}$ & $x$ & $X$ & & & & & & $\mathbf{X}$ & & & \\
\hline Peninsular & $\mathbf{X}$ & & $\mathbf{X}$ & & & & & & & & & \\
\hline Alexander & $x$ & & $X$ & & & $x$ & & & & $x$ & & \\
\hline
\end{tabular}

Figure 4. Checklist showing occurrence of different Monotis species in the accreted terranes of Alaska, the non-accretionary North American rocks of the Upper Yukon, and the Stikinia terrane of western Canada. As listed from top to bottom, terranes are in order from north to south in their inferred approximate relative paleolatitudinal and hemispheric positions. $X$, species regarded as present without qualification; $x$, probably or possibly present (in the sense of "cf." or “?”).

only two developments of true paleoequatorial Dachsteintype Upper Triassic coral reefs in North America (Stanley and Senowbari-Daryan, 1986)) is displayed, the other being in the Wallowa terrane of eastern Oregon. The implications of this for appreciable northward displacement of the Stikinia terrane relative to the craton was first recognized by Tozer (1970).

The paleogeographic meaning of the distribution of the various kinds of Monotis in the accreted terranes of Alaska is simple and obviously related to major geologic features. Low-paleolatitude faunas characterize terranes that lie to the south of the Denali fault and have been transported northward relative to North America. Monotis faunas suggest that low paleolatitude terranes south of the Denali fault, such as the Wrangellia and Susitna terranes, are structurally juxtaposed against the Nixon Fork terrane on the north side of the fault. The Nixon Fork contains an unusual association of Monotis species, generally of mid-paleolatitude kind, but as noted previously it also contains the northernmost known occurrence of Heterastridum; this terrane thus has biogeographic characteristics intermediate between those of the low-paleolatitude terranes of southern Alaska and the midpaleolatitude terranes of northern Alaska. The Monotis fauna of the small Upper Yukon region in Alaska, which is regarded as a non-accretionary part of Phanerozoic North America, resembles that of mid-paleolatitude kind. Northward displacement of Stikinia with respect to the Upper Yukon was accommodated by slip on the Tintina faultNorthern Rocky Mountain Trench (fig. 1).

The Monotis-bearing terranes and the Upper Yukon region are listed in order from north to south in figure 4 in their approximate relative paleolatitudinal and hemispheric positions as suggested by the biogeographic affinities of their Monotis and other faunas. Aside from hemispheric ambiguity in placement of paleoequatorial terranes, no significant conflict arises between this pattern and the results of paleomagnetic investigations.

\section{REFERENCES CITED}

Arkhipov, Yu.V., 1970, New zonal scheme for the Upper Triassic of the Yana River Basin: Doklady Akademii Nauk SSSR, v. 195, p. 151-154.

Arkhipov, Yu.V. and Truschelev, A.M., 1982, On biostratigraphy of Norian-Rhaetian deposits of north-eastern Asia: Akademiya Nauk SSSR, Sibirskoye Otdeleniye, Trudy Instituta Geologogii i Geofiziki, v. 462, p. 48-54.

Berg, H.C., Jones, D.L., and Coney, P.J., 1978, Map showing preCenozoic tectonostratigraphic terranes of Southeastern Alaska and adjacent areas: U.S. Geological Survey Open-File Report 78-1085, scale 1:1,000,000.

Blome, C.D., Reed, K.M., and Tailleur, I.L., 1988, Radiolarian biostratigraphy of the Otuk Formation in and near the National Petroleum Reserve, northern Alaska, in Gryc, George, ed., Geology and exploration of the National Petroleum Reserve in Alaska, 1974 to 1982: U.S. Geological Survey Professional Paper 1399, p. 725-776.

Bodnar, D.A., 1984, Stratigraphy, age, depositional environments, and hydrocarbon source rock evaluation of the Otuk Formation, North-Central Brooks Range, Alaska: M.S. thesis, University of Alaska, Fairbanks, 232 p.

Box, S.E., 1985, Terrane analysis of the northern Bristol Bay region, southwestern Alaska: U.S. Geological Survey Circular 967, p. 32-37.

Brabb, E.E., 1969, Six new Paleozoic and Mesozoic formations in east-central Alaska: U.S. Geological Survey Bulletin 1274-I, $26 \mathrm{p}$. 
Bychkov, Yu.M., and Polubotko, I.V., 1984, Upper Triassic, in Rostovstev, K. O., and Zhamoida, A. J., ed., A standard for Triassic time in the USSR: Leningrad, Ministry of Geology and USSR Academy of Sciences (in Russian), p. 63-104.

Dagys, A.S., Arkhipov, Yu.V., Bychkov, Yu.M., 1979, Stratigraphy of the Triassic System of North-Eastern Asia: Akademiya Nauk SSSR, Sibirskoye Otdeleniye, Trudy Instituta Geologogii i Geofiziki, v. 447, 243 p.

Detterman, R.L., Case, J.E., Miller, J.W., Wilson, F.H., and Yount, M.E., in press, Stratigraphic framework of the Alaska Peninsula: U.S. Geological Survey Bulletin 1969-A.

Detterman, R.L., Reiser, H.N., Brosge, W.P., and Dutro, J.T., Jr., 1975, Post-Carboniferous stratigraphy, Northeastern Alaska: U.S. Geological Survey Professional Paper 886, 46 p.

Dutro, J.T., Jr., and Silberling, N.J., 1988, Megafossil biostratigraphy of some deep test wells, National Petroleum Reserve in Alaska, in Gryc, George, ed., Geology and exploration of the National Petroleum Reserve in Alaska, 1974 to 1982: U.S. Geological Survey Professional Paper 1399, p. 667-675, pls. 30.1-30.4.

Gall, J.C., 1983, Ancient sedimentary environments and habitats of living organisms: Berlin, Springer-Verlag, $219 \mathrm{p}$.

Gardner, M.C., Bergman, S.C., Cushing, G.W., Mackevett, E.M., Jr., Plafker, G., Campbell, R.B., Dodds, C.J., McClelland, W.C., and Mueller, P.A., 1988, Pennsylvanian pluton stitching of Wrangellia and the Alexander terrane, Wrangell Mountains, Alaska: Geology, v. 16, p. 967-971.

Grant-Mackie, J.A., 1981, New Zealand Warepan (Upper Triassic) sequences: Murihiku Supergroup of the North Island: Royal Society of New Zealand Journal, v. 11, p. 31-56.

Grant-Mackie, J.A., 1986, The Warepan Stage of the Upper Triassic: Redefinition and subdivision: New Zealand Journal of Geology and Geophysics, v. 28, p. 701-724.

Grant-Mackie, J.A., and Silberling, N.J., 1990, New data on the Upper Triassic bivalve Monotis in North America and the new Subgenus Pacimonotis: Journal of Paleontology, v. 64, p. 240-254.

Haeussler, Peter, and Coe, R.S., 1992, Paleomagnetism of the Late Triassic Hound Island Volcanics: Revisited: Journal of Geophysical Research, v. 97, no. B13, p. 9617-9639.

Hillhouse, J.W., and Grommé, C.S., 1980, Paleomagnetism of the Triassic Hound Island Volcanics, Alexander Terrane, Southeastern Alaska: Journal of Geophysical Research, v. 85, no. B5, p. 2594-2602.

-1984, Northward displacement and accretion of Wrangellia: New paleomagnetic evidence from Alaska: Journal of Geophysical Research, v. 89, no. B6, p. 4461-4477.

Jones, D.L., Silberling, N.J., and Coney, P.J., 1986, Collision tectonics in the Cordillera of western North America: Examples from Alaska, in Coward, M.P., and Ries, A.C., eds., Collision tectonics: Geological Society Special Publication 19, p. 367-387.

Jones, D. L., Silberling, N. J., Coney, P. J., and Plafker, George, 1987, Lithotectonic terrane map of Alaska (west of the 141st Meridian): U.S. Geological Survey Miscellaneous Field Studies Map MF-1874-A, scale 1:2,500,000.

Jones, D.L., Silberling, N.J., Csejtey, Béla, Jr., Nelson, W.H., and Blome, C.D., 1980, Age and structural significance of ophiolite and adjoining rocks in the Upper Chulitna district, south-central
Alaska: U.S. Geological Survey Professional Paper 1121-A, $21 \mathrm{p}$.

Kauffman, E.C., 1988, The case of the missing community: lowoxygen adapted Paleozoic and Mesozoic bivalves ("flat clams") and bacterial symbioses in typical Phanerozoic seas: Geological Society of America Abstracts with Programs, v. 20, no. 7, p. A48.

Kent, D.V., and Witte, W.K., 1993, Slow apparent polar wander for North America in the Late Triassic and large Colorado Plateau rotation: Tectonics, v. 12, p. 291-300.

Kiparisova, L., 1936, Upper Triassic pelecypods from the KolymaIndigirka Land: Transactions Arctic Institute Leningrad, v. 30, p. 71-136 (in Russian and English).

Kiparisova, L.D., Bytschkov, Yu.M., and Polubotko, I.V., 1966, Upper Triassic bivalve Mollusca of northeastern USSR: VSEGEI, Magadan, 312 p. (in Russian).

Lupe, Robert, and Silberling, N.J., 1985, Genetic relationship between lower Mesozoic continental strata of the Colorado plateau and marine strata of the western Great Basin: Significance for accretionary history of Cordilleran lithotectonic terranes, in Howell, D. G., ed., Tectonostratigraphic terranes of the circum-Pacific region: Circum-Pacific Council for Energy and Mineral Resources, Earth Science Series 1, p. 63-70.

MacKevett, E.M., Jr., 1970, Geologic map of the McCarthy C-5 quadrangle, Alaska: U.S. Geological Survey GQ-899, scale $1: 63,360$.

1978, Geologic map of the McCarthy quadrangle, Alaska: U.S. Geological Survey Map I-1032, scale 1:250,000.

Monger, J.W.H., and Berg, H.C., 1987, Lithotectonic terrane map of western Canada and southeastern Alaska: U.S. Geological Survey Miscellaneous Field Studies, Map MF-1874-B, scale $1: 2,500,000$.

Mountjoy, E.W., 1967, Triassic stratigraphy of northern Yukon Territory: Geological Survey of Canada, Paper 66-19, 44 p.

Muffler, L.J.P., 1967, Stratigraphy of the Keku islets and neighboring parts of Kuiu and Kupreanof Islands, southeast Alaska: U.S. Geological Survey Bulletin 1241-C, p. C1-C52.

Mull, G.C., Tailleur, I.L., Mayfield, C.F., Ellersieck, Inyo, and Curtis, S., 1982, New upper Paleozoic and lower Mesozoic stratigraphic units, central and western Brooks Range, Alaska: American Association of Petroleum Geologists Bulletin, v. 66, p. 348-362.

Nakazawa, K., 1964, On the Monotis typica zone in Japan: Kyoto University Faculty of Science Memoirs, Geology and Mineralogy Series, v. 30, p. 21-39.

Nelson, JoAnne, and Mihalynuk, Mitch, 1993, Cache Creek ocean: Closure or enclosure?: Geology, v. 21, p. 173-176.

Newton, C.R., 1983, Paleozoogeographic affinities of Norian bivalves from the Wrangellian, Peninsular, and Alexander terranes, western North American, in Stevens, C.H., ed., PreJurassic rocks in western North American suspect terranes: Pacific Section, Society of Economic Paleontologists and Mineralogists, Los Angeles, p. 37-48.

Nokleberg, W.J., Jones, D.L., and Silberling, N.J., 1985, Origin and tectonic evolution of the Maclaren and Wrangellia terranes, eastern Alaska Range, Alaska: Geological Society of America Bulletin, v. 96, p. 1251-1270.

Panuska, B.C., and Stone, D.B., 1985, Latitudinal motion of the Wrangellia and Alexander terranes and the southern Alaska superterrane, in Howell, D.G., ed., Tectonostratigraphic 
terranes of the Circum-Pacific region: Circum-Pacific Council for Energy and Mineral Resources, Earth Sciences Series, 1, p. $109-120$.

Patton, W.W., Jr., Dutro, J.T., Jr., and Chapman, R.M., 1977, Late Paleozoic and Mesozoic stratigraphy of the Nixon Fork area: U.S. Geological Survey Circular 751-B, p. B38-B40.

Patton, W.W., Jr., and Tailleur, I.L., 1964, Geology of the KillikItkillik region, Alaska: U.S. Geological Survey Professional Paper 303-G, p. 409-500.

Reed, B.L., and Nelson, S.W., 1977, Geologic map of the Talkeetna quadrangle, Alaska: U.S. Geological Survey MF-870-A, scale $1: 250,000$.

Silberling, N.J., 1985, Biogeographic significance of the Upper Triassic bivalve Monotis in circum-Pacific accreted terranes, in Howell, D. G., ed., Tectonostratigraphic terranes of the Circum-Pacific region, Circum-Pacific Council for Energy and Mineral Resources, Earth Science Series 1, p. 63-70.

Silberling, N.J., Nichols, K.M., Bradshaw, J.D., and Blome, C.D., 1988, Limestone and chert in tectonic blocks from the Esk Head subterrane, South Island, New Zealand: Geological Society of America Bulletin, v. 100, p. 1213-1223.

Silberling, N.J., Richter, D.H., and Jones, D.L., 1981, Recognition of the Wrangellia terrane in the Clearwater Mountains and vicinity, south-central Alaska: U.S. Geological Survey Circular 823-B, p. B51-B55.

Stanley, G.D., Jr., and Senowbari-Daryan, Baba, 1986, Upper Triassic, Dachstein-type, reef limestone from the Wallowa Mountains, Oregon: First reported occurrence in the United States: Palaios, v. 1, p. 172-177.

Tozer, E.T., 1970, Marine Triassic faunas: Geological Survey of Canada, Economic Geology Report 1 (Fifth Edition), p. 633-640.

1980, Latest Triassic (Upper Norian) ammonoid and Monotis faunas and correlations: Revista Italiana di Paleontologia, v. 85 , p. 843-876.

1982, Marine Triassic faunas of North America: their significance for assessing plate and terrane movements: Geologische Rundschau, v. 71, p. 1077-1104.

Wang, Jason, Newton, C.R., and Dunne, Lorie, 1988, Late Triassic transition from biogenic to arc sedimentation on the Peninsular terrane: Puale Bay, Alaska Peninsula: Geological Society of America Bulletin, v. 100, p. 1466-1478.

Westermann, G.E.G., 1962, Succession and variation of Monotis and the associated fauna in the Norian Pine River Bridge section, British Columbia (Triassic, Pelecypoda): Journal of Paleontology, v. 36, p. 745-792.

1966, New occurrences of Monotis from Canada (Triassic Pelecypoda): Canadian Journal of Earth Science, v. 3, p. 975-986.

Westermann, G.E.G., and Verma, H., 1967, The Norian Pine River Bridge section, British Columbia, and the succession of Monotis: Journal of Paleontology, v. 41, p. 798-803.

\section{APPENDIX 1. LOCALITY DESCRIPTIONS}

U.S. Geological Survey (USGS) Mesozoic locality numbers without a letter prefix are recorded in the Reston,
Virginia, laboratory; those having the prefixes "D" and "M" are recorded, respectively, at the Denver, Colorado, and Menlo Park, California, laboratories of the U.S. Geological Survey. The only Stanford University locality number is prefixed by "SU." All of the collections to which these locality numbers pertain are currently housed in the reference collections of the U.S. Geological Survey, Denver, Colorado. Lithotectonic (also called tectonostratigraphic) terrane designations are from Jones and others (1987) and Monger and Berg (1987).

USGS Mesozoic loc. 6380. Kenai Peninsula, southern Alaska; north side of Port Graham; lat $59^{\circ} 21^{\prime} 08^{\prime \prime}$ N., long $151^{\circ} 48^{\prime}$ W. Coll.: U.S. Grant and party, 1909, field No. G662. [Seldovia 1:250,000 quadrangle; Peninsular terrane]

USGS Mesozoic loc. 6382. Kenai Peninsula, southern Alaska; south side of Port Graham; lat 59 $21^{\prime} 02^{\prime \prime}$ N., long 151 50 '24" W. Coll.: U.S. Grant and party, 1909, field No. G673. [Seldovia 1:250,000 quadrangle; Peninsular terrane]

USGS Mesozoic loc. 7234. Kenai Peninsula, southern Alaska; south shore of Port Graham, 1 and 2/5 miles below wharf. Coll.: G.C. Martin, June 28, 1911, field No. Station 61. [Seldovia 1:250,000 quadrangle; Peninsular terrane]

USGS Mesozoic loc. 9382. Yukon River, central Alaska; south bank, southwest of Nation. Coll.: Eliot Blackwelder, June 20, 1915, field No. 1507. [Charley River 1:250,000 quadrangle; in rocks not included among the Phanerozoic accretionary terranes]

USGS Mesozoic loc. 9961. Wrangell Mountains, southern Alaska; Mill Creek tributary to Lakina River on west side near forks of creek, $2 \frac{1}{2}$ miles from Lakina River; from float in gulch below cliff. Coll.: F.H. Moffit, field No. 43, Sept. 3, 1916. [McCarthy 1:250,000 quadrangle; Wrangellia terrane]

USGS Mesozoic loc. 10546. Cook Inlet, Kenai Peninsula, southern Alaska; northerly shore of Port Graham near mouth of small stream northeast from cannery, south shore of Kachemak Bay. Coll.: A.C. Gill, July 20, 1918, field No. 18-G-90. [Seldovia 1:250,000 quadrangle; Peninsular terrane]

USGS Mesozoic loc. 10168. Admiralty Island, southeastern Alaska; west side of Mole Harbor. Coll.: Edwin Kirk, August 18, 1918. [Sitka 1:250,000 quadrangle; Peninsular terrane]

USGS Mesozoic loc. 18927. Kuskokwim Mountains, southwestern Alaska; 34 miles S. $73^{\circ} \mathrm{W}$. of Kashegelok on crest of spur of ridge east of Cinnabar Creek at a point about 1 mile N. $60^{\circ} \mathrm{W}$. of the mouth of the creek. Coll.: W.M. Cady, 1943, field No. 43ACa39. [Taylor Mountain 1:250,000 quadrangle; Togiak terrane]

USGS Mesozoic loc. 23170. Kuskokwim region, southwestern Alaska; lat 59 $44^{\prime} 02^{\prime \prime}$ N., long $160^{\circ} 27^{\prime} 02^{\prime \prime}$ W.; $15 \frac{1}{2}$ miles S. $48^{\circ} \mathrm{W}$. of outlet of Kagati Lake; $11 \frac{1}{1} 2$ miles S. $70^{\circ}$ E. of mouth of Klak Creek; $15^{3 / 4}$ miles N., $6 \frac{1}{2}$ miles E. of head of Good News Lake. Fossils occur near the southeast end of a ridge that lies north of a lake about 2 miles long 
that drains into Klak Creek; the ridge starts about the center of the lake and extends northwestward; fossils in float about 900 feet above lake level and 20 feet below the crest of the ridge. Coll.: J.M. Hoare, August 18, 1950, field No. 50 AHR 590. Recollected by W.L. Coonrad and J.M. Hoare, 1975, field No. GC4-1122; Goodnews C-4 quadrangle; NE $3 / 4 \mathrm{sec}$. 23, T. 5 S., R. 66 W. [Goodnews terrane]

USGS Mesozoic loc. 24504. Colville region, northern Alaska; west side of Killik River, 12 miles north of junction with Easter Creek. Coll.: M.C. Lachenbruch, 1949, field No. 49ALac118F. [Killik River 1:250,000 quadrangle; Endicott Mountains or DeLong Mountains subterrane of the Arctic Alaska terrane]

USGS Mesozoic loc. D10708. Noyakuk Lake, southwestern Alaska; lat 5953.1' N., long 158 55.5' W.; limestone within thick section of graywacke and shale; small outcrop on south shore of lake about $0.5 \mathrm{~km}$ east of obvious promontory; Dillingham D-8 quadrangle, sec. 28, T. 3 S., R. 56 W. Coll.: J.M. Hoare, 1978, field No. 78AHr146. [Togiak(?) terrane]

USGS Mesozoic loc. D11071, D11075, D11078, and D11083. Killik River region, northern Alaska; type section of Otuk Formation on bluff on east bank of Otuk Creek: D11071, 114 feet above base; D11075, 110 feet above base; D11078, 107 feet above base; D11083, 101 feet above base of section. Coll: C.G.Mull, 1975, field No. 75AMu57. Killik River 1:250,000 quadrangle (sec. 31, T. 10 S., R. 16 W.). [Endicott Mountains subterrane of the Arctic Alaska terrane]

USGS Mesozoic loc. D11284. Kuskokwim Mountains, west-central Alaska; Medfra C-3 1:63,360 quadrangle; float from narrow strip of rubble on south side of ridge; center E $1 \frac{1}{2}$ SE $1 / 4$ sec. 12, T. 22 S., R. 24 E. Coll.: N.J. Silberling, and others, 1980, field No. 80S431. [Nixon Fork terrane]

USGS Mesozoic loc. D11285. Same locality as D11284 but bedrock on north side of ridge and 4-5 m stratigraphically higher. Coll.: N.J. Silberling, 1980, field No. 80-S-432.

USGS Mesozoic loc. D11286. Kuskokwim Mountains, west-central Alaska; Medfra C-3 1:63,360 quadrangle; bedrock on ridge crest a few tens of meters stratigraphically above float of middle Norian Halobia and several meters below float of Monotis (P.) subcircularis and Heterastridium; SE $1 / 4$ NW $1 / 4$ sec. 2, T. 22 S., R. 24 E. Coll.: N.J. Silberling, 1980, field No. 80S436. [Nixon Fork terrane]

USGS Mesozoic loc. D11287. Talkeetna region, southern Alaska; Monotis and Halobia from single $10 \mathrm{~cm}$ concretionary bed; Inoceramus? and belemnites from adjoining 1-2 $\mathrm{m}$ of section; few tens of meters above top of pillow basalt. Coll.: N.J. Silberling, 1980, field No. 80-S-382. Talkeetna C-6 quadrangle (center E edge, NE $1 / 4$ sec. 14, T. 30 N., R. 19 W.). [McKinley terrane]

USGS Mesozoic loc. D11289. Alaska Peninsula, southwestern Alaska; Karluk C-4 and C-5 quadrangle; limestone 2 miles N. $81^{\circ}$ E. of VABM Kek; lat 57²44'30" N., long
155¹7'20" W. Coll.: R.L. Detterman, 1980, field No. 80ADt170. [Peninsular terrane]

USGS Mesozoic loc. D12569. Talkeetna Mountains, southern Alaska; Healy A-5 quadrangle; float from interbedded tuffaceous sedimentary rocks and basalt; center $\mathrm{S} 1 / 2$ NW $1 / 4$ sec. 24, T. 20 S., R. 9 W. Coll.: N.J. Silberling, 1977, field No.77S152. [Susitna terrane]

USGS Mesozoic loc. D12582, D12583, and D12584. Northern Alaska; Philip Smith Mountains 1:250,000 quadrangle; northwest side of Atigun River in "Atigun Gorge"; center $\mathrm{W}^{1 / 2} \mathrm{E}^{1 / 2} \mathrm{NE}^{1 / 4}$ sec. 23, T. 11 S., R. 12 E.; D12582, at 70 feet in measured section and $1.5 \mathrm{~m}$ stratigraphically below $0.5 \mathrm{~m}$ calcareous glauconitic sandstone that may be a tongue of the Karen Creek Sandstone at the top of the Otuk Formation; D12583, at 63 feet in measured section; D12584, at 58-59 feet in measured section. Coll.: N.J. Silberling, 1976, field No. 76S221. [Endicott Mountains subterrane of the Arctic Alaska terrane]

USGS Mesozoic loc. D12594 and D12595. Fire Creek region, northern Alaska; reference section for the Shublik Formation on Fire Creek, 6 miles N. $80^{\circ} \mathrm{W}$. from junction of Fire Creek with Sadlerochit River, lat 69³1'45" N., long $145^{\circ} 12^{\prime} 20^{\prime \prime}$ W.: D12594, basal 1.5 m of Karen Creek Sandstone, 460 feet above base of Shublik Formation; D12595, unit 6, \#2, 450 feet above base of Shublik Formation. Coll.: R.L. Detterman, 1969, field Nos. 69ADt-106 and 69ADt-105. [Mt. Michelson 1:250,000 quadrangle; North Slope subterrane of the Arctic Alaska terrane]

USGS Mesozoic loc. D12609 and D12610. Northern Alaska, National Petroleum Reserve in Alaska; core samples from West Dease Test Well No. 1; lat $71^{\circ} 09^{\prime}$ N., long 155³7' W.; D12609, 3,915 feet depth; D12610, 3,919.1 feet depth. [North Slope subterrane of the Arctic Alaska terrane]

USGS Mesozoic loc. D12613 through D12617. Northern Alaska, National Petroleum Reserve in Alaska; core samples from Simpson Test Well No. 1; lat 7057'12" N., long $155^{\circ} 21^{\prime} 52^{\prime \prime}$ W.; D12613, 6,318.2 feet depth; D12614, 6,312 feet depth; D12615, 6,310 feet depth; D12616, 6,306 feet depth; D12617, 6,304 feet depth. [North Slope subterrane of the Arctic Alaska terrane]

USGS Mesozoic loc. D13388. Port Graham region, southern Alaska; north shore line of Port Graham, south of Selenie Lagoon, lat 59²2.07' N., long 151 ${ }^{\circ} 51.15^{\prime}$ W. Coll.: Béla Csejtey, 1991, field no. 91ACy-7. [Seldovia B-5 quadrangle; Peninsular terrane]

USGS Mesozoic loc. M749. Alaska Peninsula, southwestern Alaska; on coast near point between Cape Kekurnoi and Puale Bay about $1 / 2$ mile NE. from cabin near VABM 96 on Karluk 1:250,000 quadrangle; Monotis occurs about 400 feet above base(?) of Triassic section and 250-300 feet above coralline limestone that rests on Permian(?). Coll.: M.C. Lachenbruch, 1959, field No. ADB-123F. [Karluk 1:250,000 quadrangle; Peninsular terrane]

USGS Mesozoic loc. M1020. Upper Yukon, eastcentral Alaska; Charley River A-2 1:63,360 quadrangle; 
about 7 miles south of mouth of Nation River; west bank of Trout Creek opposite mouth of tributary from east; 1 at $65^{\circ} 05.3^{\prime}$ N., long $141^{\circ} 41.7^{\prime}$ W. Coll.: E.E. Brabb, 1960, field No. 60ABa732. [In rocks not included among the Phanerozoic accretionary terranes]

USGS Mesozoic loc. M1690. Wrangell Mountains, southern Alaska; nose of spur between head of East Ford Creek and "Anticline Valley"; 280 feet above base of McCarthy Formation, measured by Abney level; McCarthy C-5 quadrangle, central E $1 / 2$ sec.16, T. 4 S., R. 15 E. Coll.: N.J. Silberling, July 11, 1962, field No. 62-49. [Wrangellia terrane]

USGS Mesozoic loc. M1691. Wrangell Mountains, southern Alaska; nose of spur between head of East Ford Creek and "Anticline Valley"; 310 feet above base of McCarthy Formation, measured by Abney level; McCarthy C-5 quadrangle, central E $1 \frac{1}{2}$ sec.16, T. 4 S., R. 15 E. Coll.: N.J. Silberling and R.W. Imlay, July 11, 1962, field No. 6220. [Wrangellia terrane]

USGS Mesozoic loc. M1692. Wrangell Mountains, southern Alaska; McCarthy C-5 1:63,360 quadrangle; nose of spur between head of East Fork Creek and "Anticline Valley"; center E1/2 sec. 16, T. 4 S., R. 15 E.; 415 feet above base of the McCarthy Formation. Coll.: N.J. Silberling, 1962, field No. 62-21. [Wrangellia terrane]

USGS Mesozoic loc. M1693. Same as for locality M1692, but 475 feet above base of the McCarthy Formation. Coll.: N.J. Silberling, 1962, field No. 62-22.

USGS Mesozoic loc. M1700. Wrangell Mountains, southern Alaska; McCarthy C-4 1:63,360 quadrangle; collection from single bed about 70 feet below top of cliff-forming unit in lower part of McCarthy Formation on S. side of Monotis Creek alongside lower rock glacier; lat $61^{\circ} 32.10^{\prime}$ N., long $142^{\circ} 25.75^{\prime}$ W. Coll.: N.J. Silberling, 1962, field No. 62-24. [Wrangellia terrane]

USGS Mesozoic loc. M1701. Same as for M1700, but from single bed about 10 feet stratigraphically lower. Coll.: N.J. Silberling, 1962, field No. 62-25.

USGS Mesozoic loc. M1714. Upper Yukon region, east-central Alaska; Charley River A-2 1:63,360 quadrangle; black papery shale several tens of feet above Trout Creek on its west side; center NE $1 / 4 \mathrm{NW}^{1 / 4} \mathrm{SW}^{1 / 4}$ sec. 17 , T. 3 N., R. 30 E. Coll.: N.J. Silberling, 1962, field No. 62-9. [In rocks not included among the Phanerozoic accretionary terranes]

USGS Mesozoic loc. M1715. Upper Yukon region, east-central Alaska; same general locality as M1714, but 10-30 feet stratigraphically higher; lenticular gray-brown limestone beds more or less equivalent to M1716. Coll.: N. J. Silberling, field No. 62-8. [In rocks not included among the Phanerozoic accretionary terranes]

USGS Mesozoic loc. M1716. Upper Yukon region, east-central Alaska; farthest upstream of pre-Tertiary outcrops; west bank of Trout Creek at water line; dark bituminous papery calcareous shale with Monotis upstream from, but more or less stratigraphically equivalent to, M1715;
Charley River A-2 quadrangle, SE1/4NE1/4NW $1 / 4 \mathrm{SW}^{1 / 4} \mathrm{sec}$. 17, T. 3 N., R. 30 E. Coll.: N. J. Silberling, June 29, 1962, field No. 62-4. [In rocks not included among the Phanerozoic accretionary terranes]

USGS Mesozoic loc. M1879. Southwestern Alaska; Russian Mission C-3 quadrangle; base of bedrock cliff forming north bank of Kuskokwim River about 14 miles S. $89^{\circ}$ W. of Aniak and about 12 miles N. $76^{\circ}$ E. of Kalskag; lat

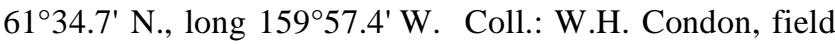
No. 63ACo380. [Terrane asssigment uncertain; possibly Nyac terrane]

USGS Mesozoic loc. M1898. Keku Strait, southeastern Alaska; at triangulation station Lee and along strike for about 1/10 mile on either side; about 130 feet above 63-S152, north shore of Hamilton Bay about $1 \frac{1}{2}$ miles west of head of bay. Coll.: N.J. Silberling, June 1963, field No. 63S-161. [Petersburg D-6 quadrangle; Alexander terrane]

USGS Mesozoic loc. M1900. Keku Strait, southeastern Alaska; middle of east side of Hound Island; same locality as 63-S-202, but from thin-bedded limestone about 10 feet stratigraphically lower. Coll.: N.J. Silberling, June 1963, field No. 63-S-202A. [Petersburg quadrangle D-6 quadrangle; Alexander terrane]

USGS Mesozoic loc. M1912. Admiralty Island, southeastern Alaska; north shore of tidal inlet directly west of triangulation station "Luck" from limestone overlying Triassic volcanic rocks and 17,750 feet S. 07 E. from triangulation station "Low." Coll.: N.J. Silberling and L.J.P. Muffler, July 1, 1963, field No. 63-AMp-259. [Sitka A-1 quadrangle; Alexander terrane]

USGS Mesozoic loc. M2143. East-central Alaska; collections from traverse taped in $\mathrm{N} .45^{\circ} \mathrm{W}$. direction along SW. bank of Yukon River beginning 835 feet N. $50^{\circ}$ W. from rocky point formed of the Tahkandit Limestone; about 6 feet of calcareous shale beginning at 27 feet traverse distance above base of section; lat $65^{\circ} 11.1^{\prime} \mathrm{N}$., long $141^{\circ} 42.3^{\prime} \mathrm{W}$. Coll.: M. Churkin, 1963, field No. 63ACn 2781D. [Charley River A-2 quadrangle; in rocks not included among the Phanerozoic accretionary terranes]

USGS Mesozoic loc. M2156. Northern Alaska; south bank of Kukpuk River; lat 68 $17^{\prime} 25^{\prime \prime}$ N., long $165^{\circ} 38^{\prime} 40^{\prime \prime} \mathrm{W}$. 22-24 feet stratigraphically below apparent top of vertically dipping section of "Shublik" [= Otuk] Formation. Coll.: I.L. Tailleur, 1963, field No. 63ATr 330. [Point Hope 1:250,000 quadrangle; Endicott Mountains subterrane of the Arctic Alaska terrane]

USGS Mesozoic loc. M2157. Same locality and field number as USGS Mesozoic loc. M2156, but 27 feet stratigraphically below apparent top of section.

USGS Mesozoic loc. M2541. Northwestern Alaska; from measured section at Noyalik Point; 61 feet above base of section, "Shublik" [= Otuk] Formation; lat $166^{\circ} 11^{\prime} \mathrm{W}$., long 6845'30" N. Coll.: I.L. Tailleur, 1964; field No. 64AMm 248. [Point Hope 1:250,000 quadrangle; subterrane 
transitional between Endicott Mountains and North Slope subterranes of Arctic Alaska terrane]

USGS Mesozoic loc. M2545. Northern Alaska; Pt. Hope 1:250,000 quadrangle; Ipewik River; upper 8 feet of exposed 55 foot-thick section of "Shublik" [= Otuk] Formation; lat $68^{\circ} 24.5^{\prime}$ N., long $165^{\circ} 39^{\prime}$ W. Submitted by: I.L. Tailleur, field No. 64AAn61. [Subterrane transitional in character between North Slope and Endicott Mountains subterranes of the Arctic Alaska terrane]

USGS Mesozoic loc. M2546. Northwestern Alaska; measured section of "Shublik" [= Otuk] Formation about 5 miles NNW. of Mt. Hamlet, 0-15 feet below top of section; lat $166^{\circ} 00^{\prime}$ W., $68^{\circ} 48^{\prime} 30^{\prime \prime}$ N. Coll.: I. L. Tailleur, 1964; field No. 64AAn 114. [Point Hope 1:250,000 quadrangle; subterrane transitional in character between North Slope and Endicott Mountains subterranes of the Arctic Alaska terrane]

USGS Mesozoic loc. M2552. Northern Alaska; Point Hope 1,250,000 quadrangle; single slab from "Shublik" [= Otuk] Formation about 8 miles south-southeast of Mt. Hamlet; $165^{\circ} 47^{\prime}$ W., $68^{\circ} 40^{\prime}$ N. Coll.: I.L. Tailleur, field No. 64ATr120. [Subterrane transitional in character between North Slope and Endicott Mountains subterranes of the Arctic Alaska terrane]

USGS Mesozoic locs. M2650, M2651, and M2652. Northeastern Alaska; Mt. Michelson 1:250,000 quadrangle; stratigraphic section No. 12 along Fire Creek at front of Shublik Mts.; SW 1/4 SW 1/4 sec. 11 to NE 1/4NE 1/4 sec. 15, T. 2 N., R. 28 E.; M2650, field No. AG 1044, 345 feet above base of Shublik Formation; M2651, field No. AG 1045, 352 feet above base of Shublik Formation; M2652, field No. AG 1046, 360 feet above base of Shublik Formation. Coll.: BP Exploration Co. (Alaska), Inc., 1964. [North Slope subterrane of the Arctic Alaska terrane]

USGS Mesozoic locs. M5058 and M5059. Northeastern Alaska; section in gorge of Fire Creek, east end of Shublik Mts., lat $69^{\circ} 31.6^{\prime}-32.0^{\prime} \mathrm{N}$., long $145^{\circ} 11.8-12.5^{\prime} \mathrm{W}$.; M5058, 380-395 feet above base of Shublik Formation; M5059, 275-370 feet above base of Shublik Formation.
Coll.: H.A. Tourtelot and I.L. Tailleur, 1968, field Nos. 68 ATo 2-27 and 68ATo 2-25. [Mt. Michelson 1:250,000 quadrangle; North Slope subterrane of the Arctic Alaska terrane]

USGS Mesozoic loc. M5113. Northern Alaska; old cutbank on east side of Ipnavik River, 10-12 feet above base of the limestone member of the Otuk Formation; lat $68^{\circ} 40.6^{\prime}$ N., long $157^{\circ} 3.5^{\prime}$ W. Coll.: H.A. Tourtelot, 1968, field No. 68ATo 23W. [Howard Pass 1:250,000 quadrangle; Endicott Mountains subterrane of the Arctic Alaska terrane]

USGS Mesozoic loc. M5115. Northern Alaska; same locality as M5113; upper 3 feet of the limestone member of the Otuk Formation. Coll.: H. A. Tourtelot, 1968, field No. 68ATo23Z.

USGS Mesozoic loc. M6624. Northeastern Brooks Range, northern Alaska; Fire Creek, 6 miles N. $80^{\circ}$ W. of junction with Sadlerochit River, lat 69 $31^{\prime} 45^{\prime \prime}$ N., long $145^{\circ} 12 ' 20 "$ W; unit 6. Coll.: R. L. Detterman, 1970, field No. 70ADt-105. [Mt. Michelson 1:250,000 quadrangle; North Slope subterrane of the Arctic Alaska terrane]

USGS Mesozoic loc. M6657. Alaska Range, southern Alaska; 2.25 miles southwest of the Eldridge Glacier at elevation 5,110 feet; lat $62^{\circ} 58^{\prime} 25^{\prime \prime} \mathrm{N}$., long $150^{\circ} 07^{\prime} 50^{\prime \prime} \mathrm{W}$.; Talkeetna D-1 quadrangle; section 25, T. 22 S., R. 14 W. Coll.: Bruce Reed, 1976. [Chulitna terrane]

USGS Mesozoic loc. M6671. Southwestern Alaska; lat $59^{\circ} 37^{\prime 2} 22^{\prime \prime}$ N., long $160^{\circ} 38^{\prime} 55^{\prime \prime}$ W. Coll.: W. L. Coonrad and J. M. Hoare, 1976, field No. GC5-1739. [Goodnews C-5 quadrangle; Goodnews terrane]

USGS Mesozoic loc. M6674. Northern Alaska; east tributary to Saviukviayak River, lat $68^{\circ} 57^{\prime}$ N., long $148^{\circ} 08^{\prime}$ W. Coll.: H.A. Tourtelot, 1968, field No. 68ATo18. [Philip Smith Mountains 1:250,000 quadrangle; North Slope subterrane of the Arctic Alaska terrane]

Stanford Univ. loc SU 3652. Alaska Peninsula, southwestern Alaska; Karluk C-4 and C-5 1:63,360 quadrangle; east side of Puale Bay about 2,300 feet N. $40^{\circ}$ W. of VABM Hike. Coll.: W.T. Rothwell, Jr., 1962, field No. ROC 1113. [Peninsular terrane] 


\section{PLATES 1-11}

[Contact photographs of the plates in this report are available, at cost, from U.S. Geological Survey Library, Denver Federal Center, Denver, CO 80225] 


\section{PLATE 1}

[All figures natural size]

Figures 1-14. Monotis from USGS Mesozoic loc. M1912 (collected from single $0.5 \mathrm{~m}$ bed along with more than 45 species of other bivalves, ammonites, gastropods, and other invertebrates of the Cordilleranus Zone).

1-3, 11-12. M. (Entomonotis) cf. M. (En.) ochotica densistriata. All left valves.

4-10, 13-14. M. (Pacimonotis) subcircularis.

4-5, 9-10. Right valves.

6-8, 13-14. Left valves.

15-16. Halobia and Monotis from USGS Mesozoic loc. M1900 (collected from a few meters of bedrock).

15. Halobia cf. H. fallax.

16. Monotis (Eomonotis) ?pinensis. Left valve.

17-21. Monotis (Pacimonotis) subcircularis. USGS Mesozoic loc. M1898.

17, 20. Right valves.

18-19, 21. Left and right valves. 


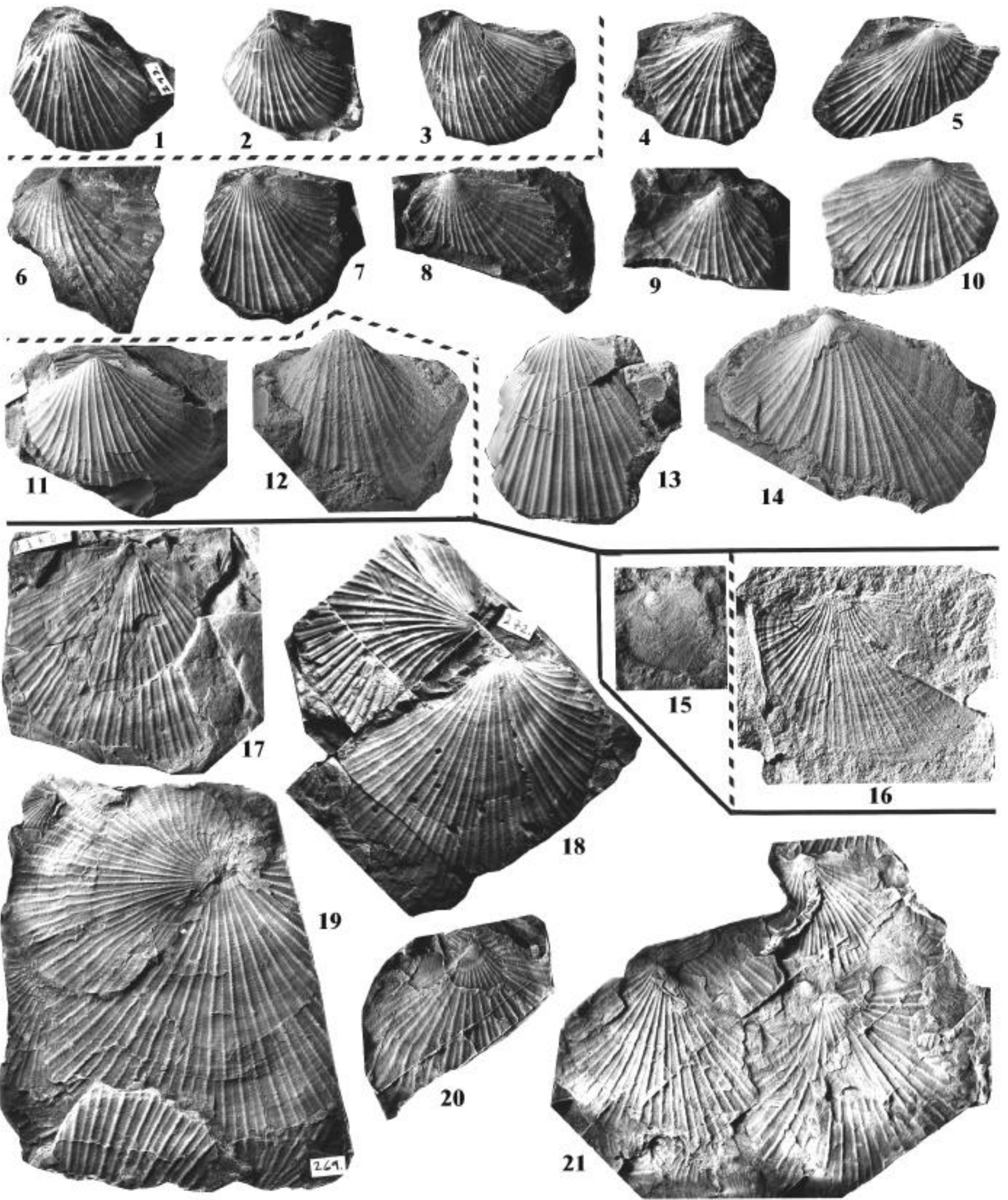




\section{PLATE 2}

[All figures natural size]

Figures 1-7. Monotis (Monotis) alaskana.

1-6. SU loc. 3652.

1-2. Left valves.

3-6. Right valves.

7. USGS Mesozoic loc. D11289 (approximately same stratigraphic level as SU loc. 3652). Left (top) and right (bottom) valves.

8-13. Monotis (Pacimonotis) subcircularis. USGS Mesozoic loc. M749 (stratigraphically lower than SU loc. 3652).

8-10. Left valves.

11-13. Right valves. 

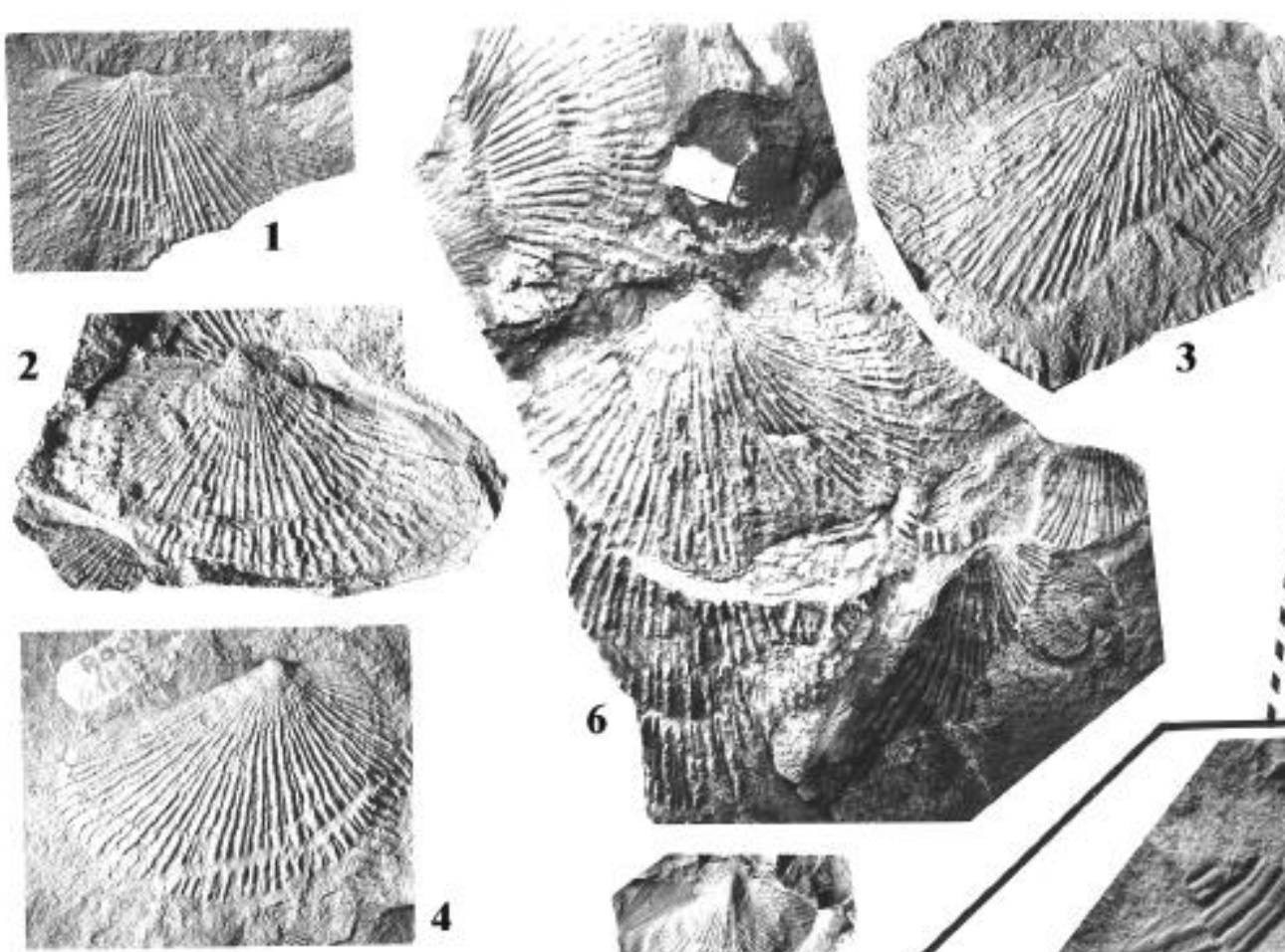

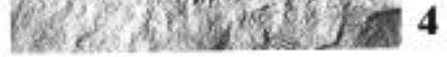
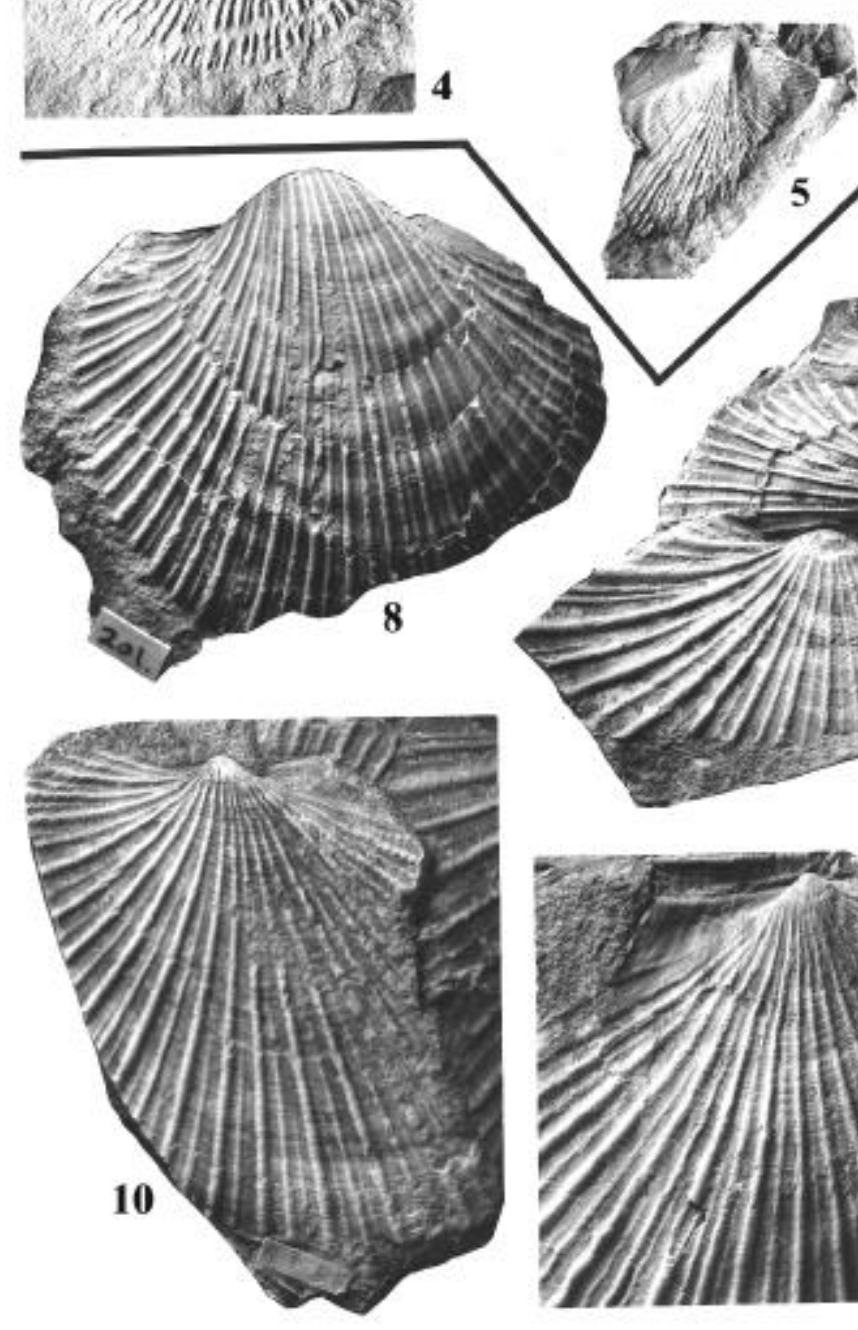


\section{PLATE 3}

[All figures natural size]

Figures 1-3. Monotis (Pacimonotis) subcircularis. USGS Mesozoic loc. M1691.

1. Left valve.

2,3. Right valves.

4-7. Monotis (Monotis) alaskana. USGS Mesozoic loc. M1692 (32 m stratigraphically above loc. M1691).

4, 7. Right valves.

5, 6. Left valves.

8-13. Monotis (Monotis) ?haueri. USGS Mesozoic loc. M1693 (18 m stratigraphically above loc. M1692).

8, 11-13. Right valves.

9-10. Left valves.

14-15. Monotis (Monotis) ?alaskana. USGS Mesozoic loc. M1700. Left and right valve.

16-20. Monotis from USGS Mesozoic loc. M1701 (collected from single bed $3.3 \mathrm{~m}$ stratigraphically lower than loc. M1700).

16-17. M. (Eomonotis) jakutica. Left valves.

18-19. M. (P.) ?subcircularis. Right valves.

20. M. (P.) subcircularis. Left valve. 

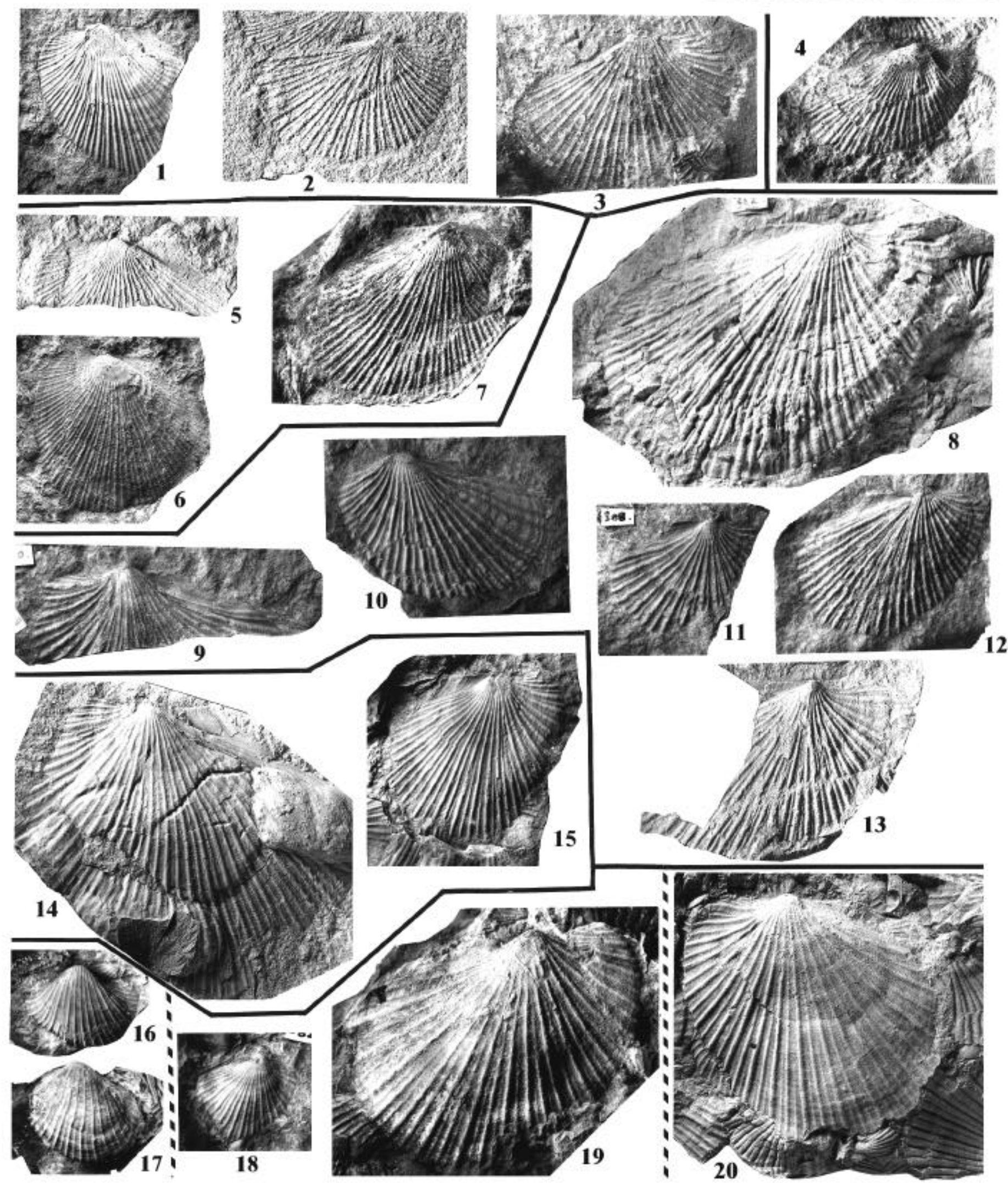

WRANGELLIA TERRANE 


\section{PLATE 4}

[All figures natural size]

Figures 1-5. Monotis (Pacimonotis) subcircularis.

USGS Mesozoic loc. M1690 (10 m stratigraphically

lower than loc. M1691). Wrangellia terrane.

$1-3$. Left valves.

4-5. Right valves.

6-8. Monotis from USGS Mesozoic loc. D12569 (collected from float).

Susitna terrane.

6-7. M. (M.) alaskana. Right and left valves.

8. $M .(P$.$) ?subcircularis. Left valve.$

9-10. Monotis (P.) ?subcircularis. USGS Mesozoic loc. M6657. Chulitna terrane.

11-13. Monotis (Monotis) salinaria. Siriuskogel, Salzkammergut, Austria, the type locality of the species. Figured for comparison with Alaskan specimens of $M$. (Monotis).

11. Left valve.

12. Right valve.

13. Right and left valves. 

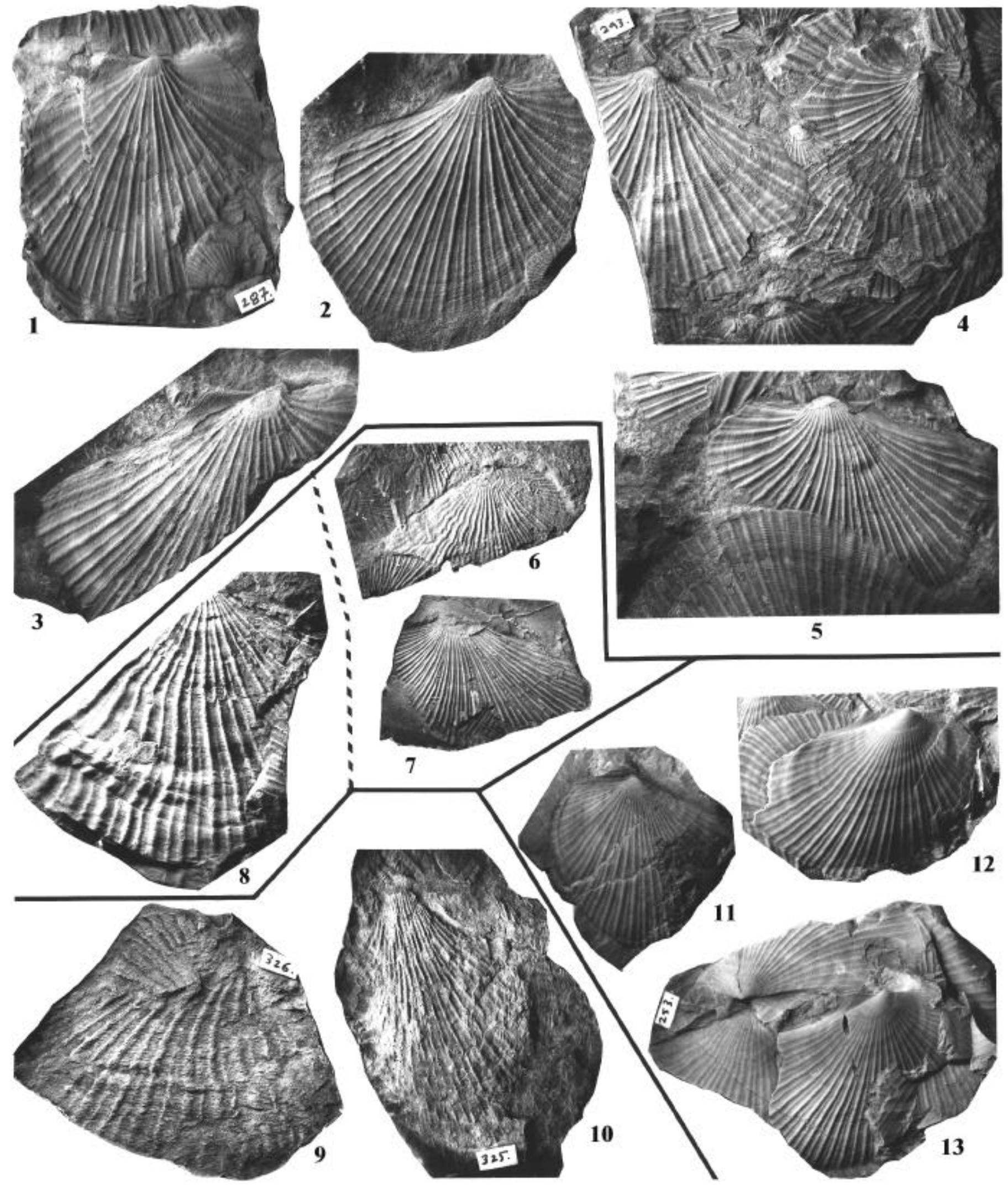

WRANGELLIA, SUSITNA, CHULITNA TERRANES 


\section{PLATE 5}

[All figures natural size]

Figures 1-4. Monotis (Pacimonotis) subcircularis.

USGS Mesozoic loc. D11285 (bedrock collection). Nixon Fork terrane.

1-3. Left valves.

4. Right valve.

5-10. Monotis from USGS Mesozoic loc. D11284 (float from about 2-m-wide strip of rubble exposed through tundra vegetation and 4-5 m stratigraphically below D11285). Nixon Fork terrane.

5. M. (Eomonotis) ?typica. Right valve.

6. M. (Monotis) sp. indet. Left valve.

7-10. M. (Eomonotis) jakutica.

7. Left valves.

8-10. Right valves.

11-16. Monotis (Eomonotis) anjuensis. USGS Mesozoic loc. D11286 (bedrock collection several meters stratigraphically below float of M. (M.) subcircularis and Heterastridium sp.). Nixon Fork terrane.

11-14, 16. Right valves.

15. Left valve.

17-22. Halobia and Monotis from USGS Mesozoic loc. D11287 (single bedrock slab, possibly redeposited into Jurassic or Cretaceous flysch). McKinley terrane.

17. Halobia cf. H. fallax.

18, 20-22. Monotis (Eomonotis) ?pinensis. Width to height ratios tectonically deformed.

18, 21. Right valves.

20, 22. Left valves.

19. Monotis (Eomonotis) ?pinensis and Halobia cf. H. fallax. 


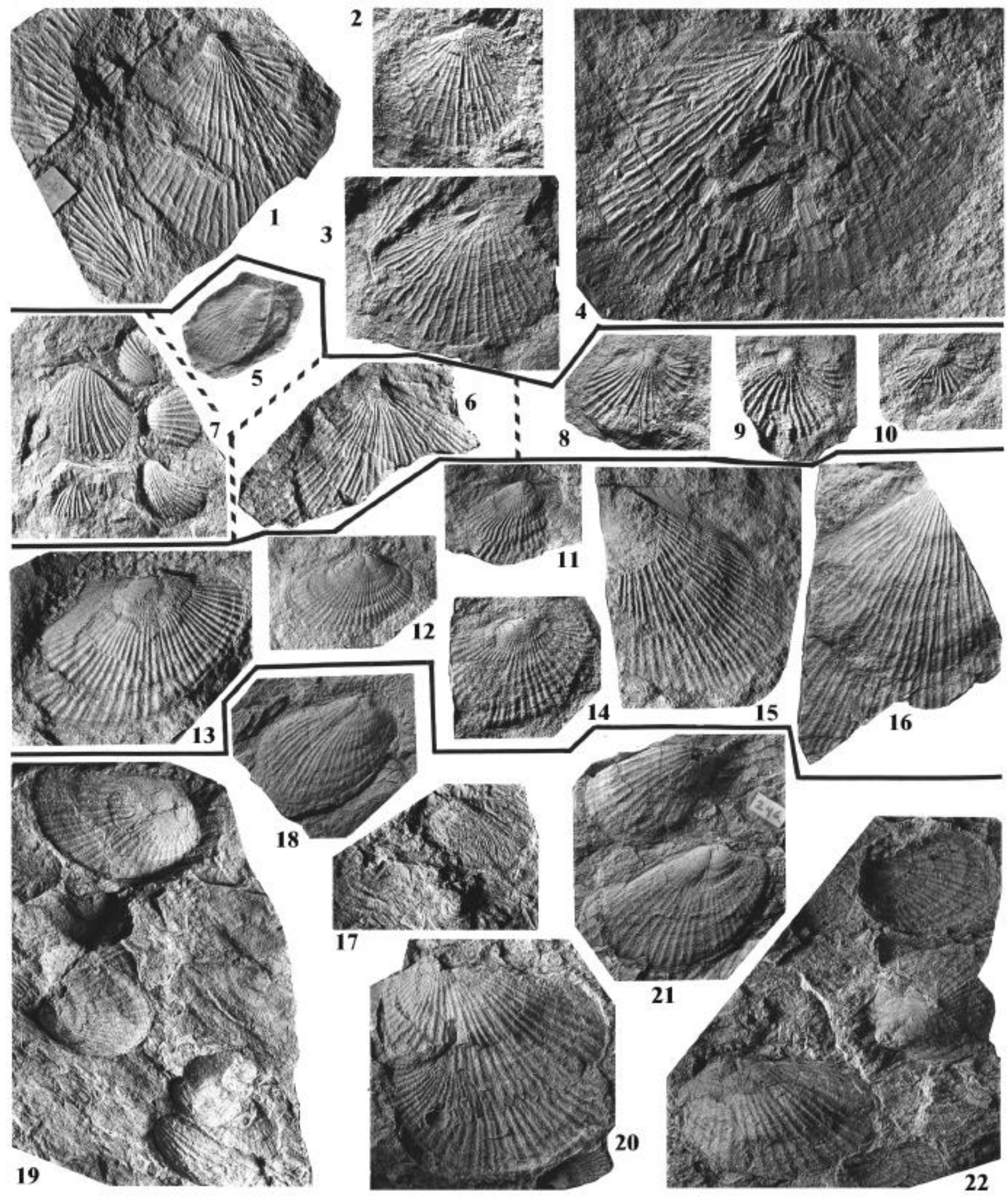




\section{PLATE 6}

[All figures natural size]

Figures 1-5. Monotis (Eomonotis) daonellaeformis.

1-4. On slabs with Halobia fallax (for example, upper right of fig. 4), USGS Mesozoic loc. M1714.

5. Left valve from USGS Mesozoic loc. M1020 (approximately same locality as loc. M1714).

6-16. Monotis (Eomonotis) ?pinensis and the associated ammonite Himavatites.

6-11. USGS Mesozoic loc. M1715 (several meters stratigraphically above loc. M1714).

6. Right and left valves.

7-8. Left valves.

9-10. Right valves.

11. ?Himavatites cf. H. multiauritis.

12-16. USGS Mesozoic loc. M1716 (approximately same stratigraphic level as loc. M1715).

12, 15. Right valve.

13, 14. Left and right valves (left valve on right side of fig. 13).

16. Slab with the associated ammonite Neohimavatites $\mathrm{cf} . \mathrm{N}$. canadensis. 


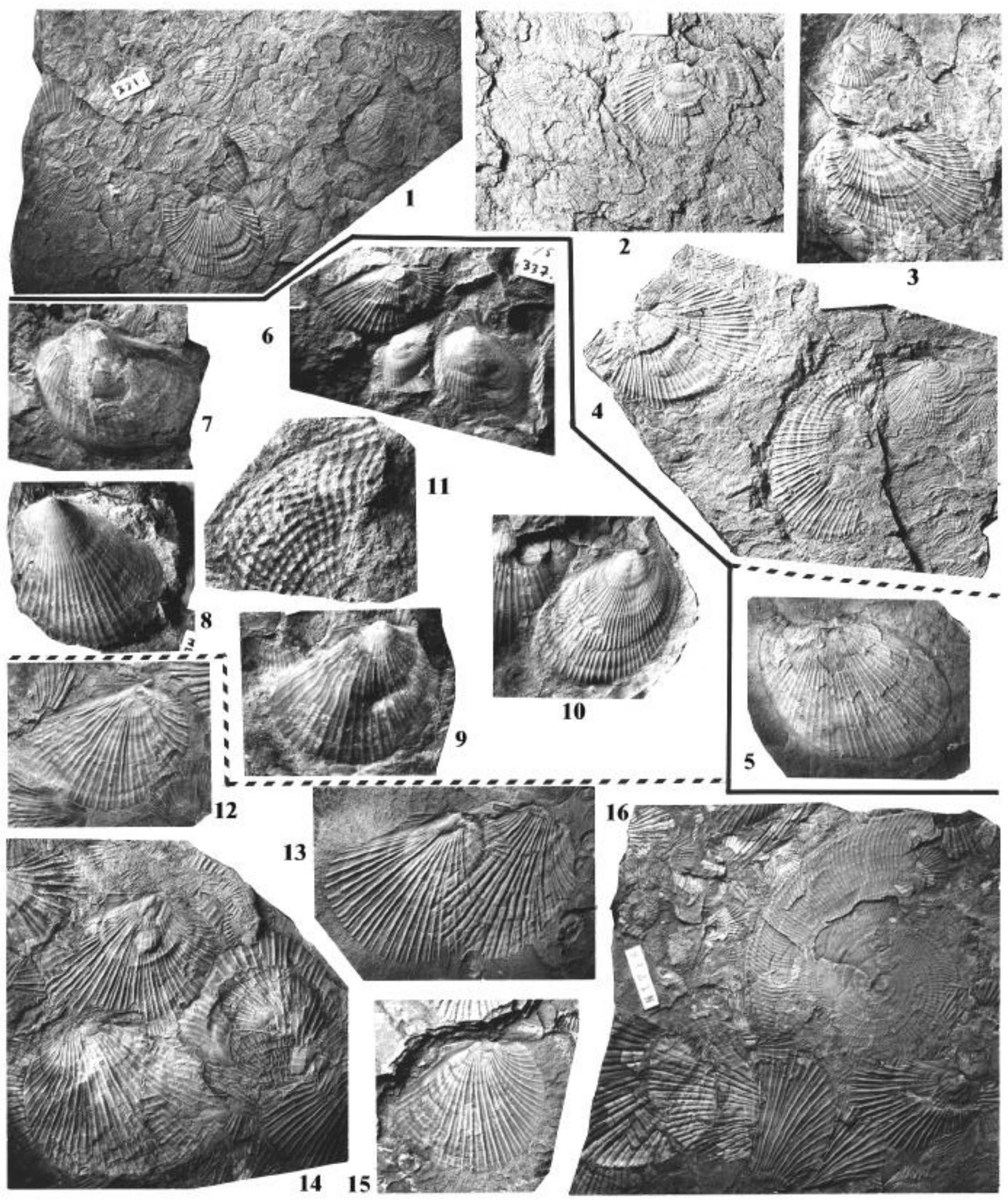




\section{PLATE 7}

[All figures natural size]

Figures 1-3. Monotis (Pacimonotis) ?subcircularis. Non-accretionary Monotis-bearing rocks, Upper Yukon region.

1-2. Interfering shells and impressions from USGS Mesozoic loc. M2143.

3. Left valve from USGS Mesozoic loc. 9382.

4-5. Monotis (P.) subcircularis. USGS Mesozoic loc. 24504. Endicott Mountains subterrane of the Arctic Alaska terrane. Two views of single bedding surface. 


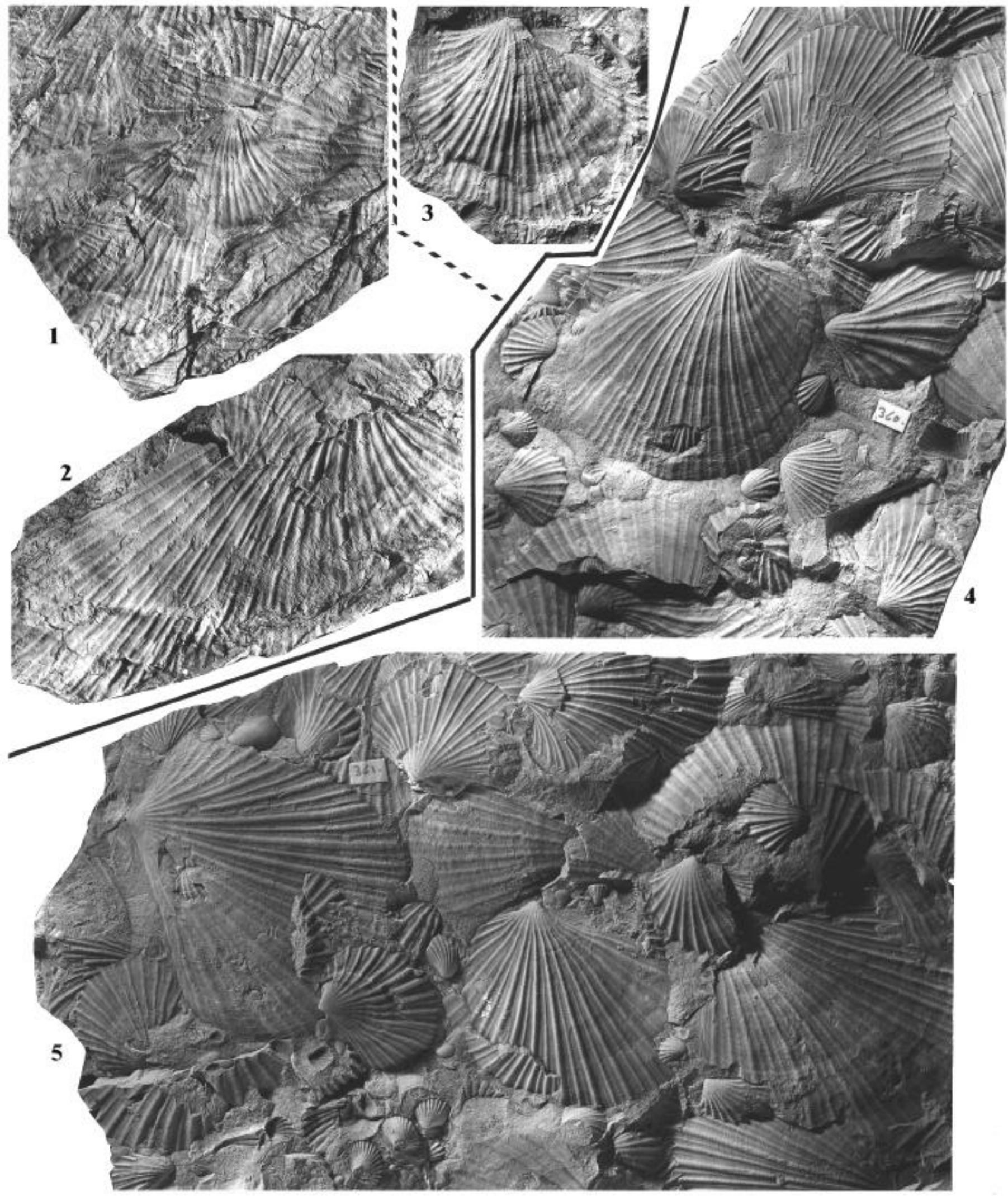




\section{PLATE 8}

[All figures natural size]

Figures 1-8. Monotis from the type section of the Otuk Formation.

1-2. Monotis (Pacimonotis)? subcircularis. Interfering shell impressions. USGS Mesozoic loc. D11071.

3. M. (Eomonotis) ?typica. Right valve. USGS Mesozoic loc. D11075 (1.2 m stratigraphically below loc. D11071).

4. M. (Eo.) ?typica. USGS Mesozoic loc. D11078 (0.9 m stratigraphically below D11075).

5-8. M. (Eo.) typica. USGS Mesozoic loc. D11083 (1.75 m stratigraphically below loc. 11078).

5-7. Right valves.

8. Left valves.

9-17. Monotis and Halobia from measured section of Otuk Formation on the Atigun River.

9. Monotis (Monotis) haueri. Right valves.

USGS Mesozoic loc. D12582 (1.5 m stratigraphically below $0.5 \mathrm{~m}$ of calcareous glauconitic sandstone that may be a tongue of the Karen Creek Sandstone at the top of the Otuk Formation).

10. M. (Eomonotis) ?typica. USGS Mesozoic loc. D12583 (ca. $2.0 \mathrm{~m}$ stratigraphically below loc. D12582).

11-17. Halobia and Monotis from USGS Mesozoic loc. D12584 (ca. $3.5 \mathrm{~m}$ stratigraphically below loc. D12582).

11-12. Halobia cf. H. fallax.

13, 15, 17. Monotis (Eomonotis) typica. Mostly right valves.

14, 16. M. (Eo.) typica. Left valves. 


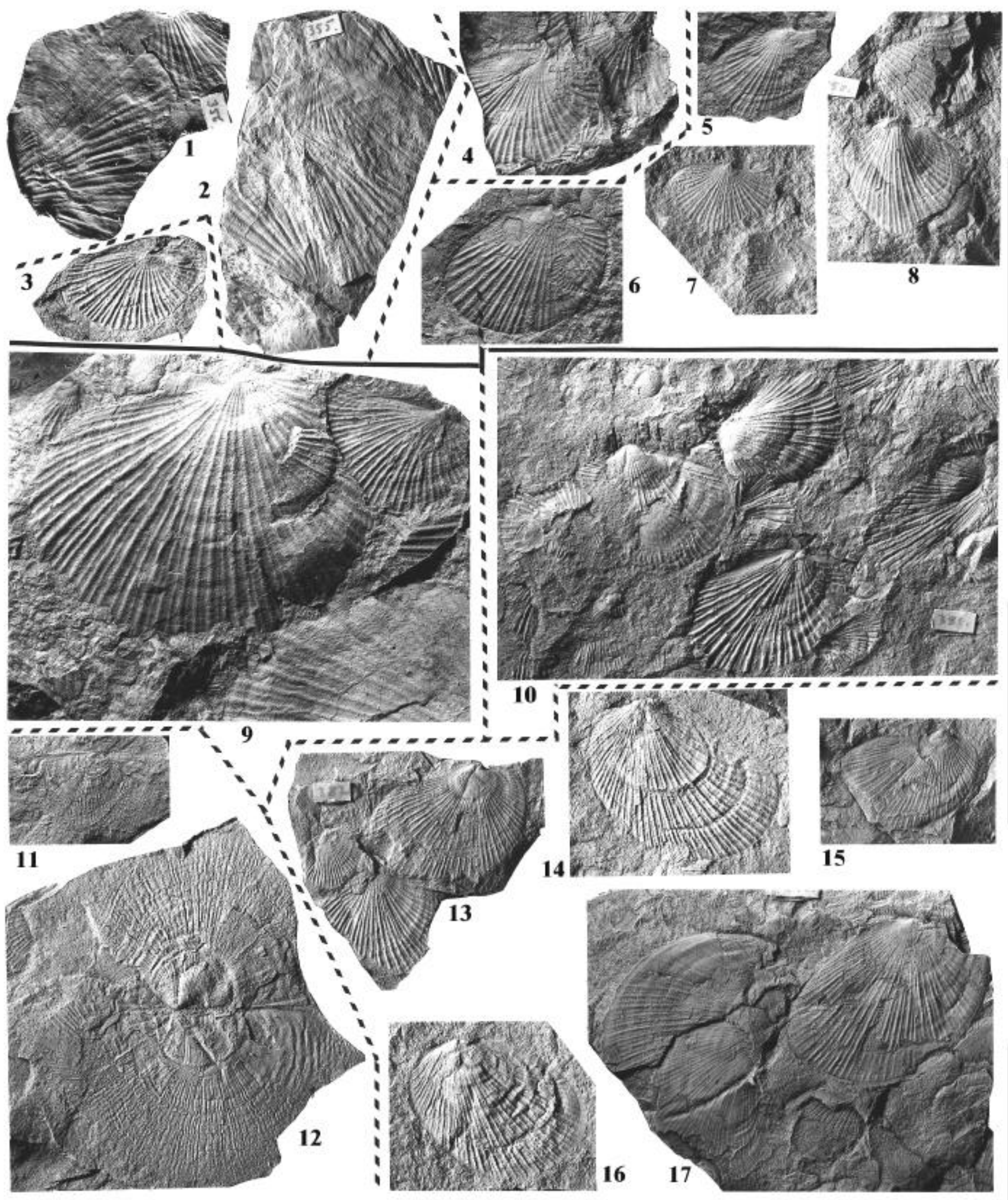




\section{PLATE 9}

[All figures natural size]

Figures 1-4, 9-11. Monotis (Entomonotis) pachypleura.

1-4. USGS Mesozoic loc. M2552 (collected from single slab of float). Left valves and one right valve (fig. 2).

9-11. USGS Mesozoic loc. M2545 (uppermost $2.5 \mathrm{~m}$ of Otuk Formation, as exposed). Mainly right valves; left valve in center of fig. 9

5-6. Monotis (Pacimonotis) subcircularis. USGS Mesozoic loc. M5115. Right and left valves.

7. Monotis (Eomonotis) ?typica. USGS Mesozoic loc. M5113 (less than $3 \mathrm{~m}$ stratigraphically below loc. M5115).

8, 12-13. M. (Entomonotis) ochotica ochotica.

8. USGS Mesozoic loc. D12581 (Otuk Formation, Tiglukpuk Creek). Left (lower) and right (upper) valves.

12-13. USGS Mesozoic loc. D10999. 


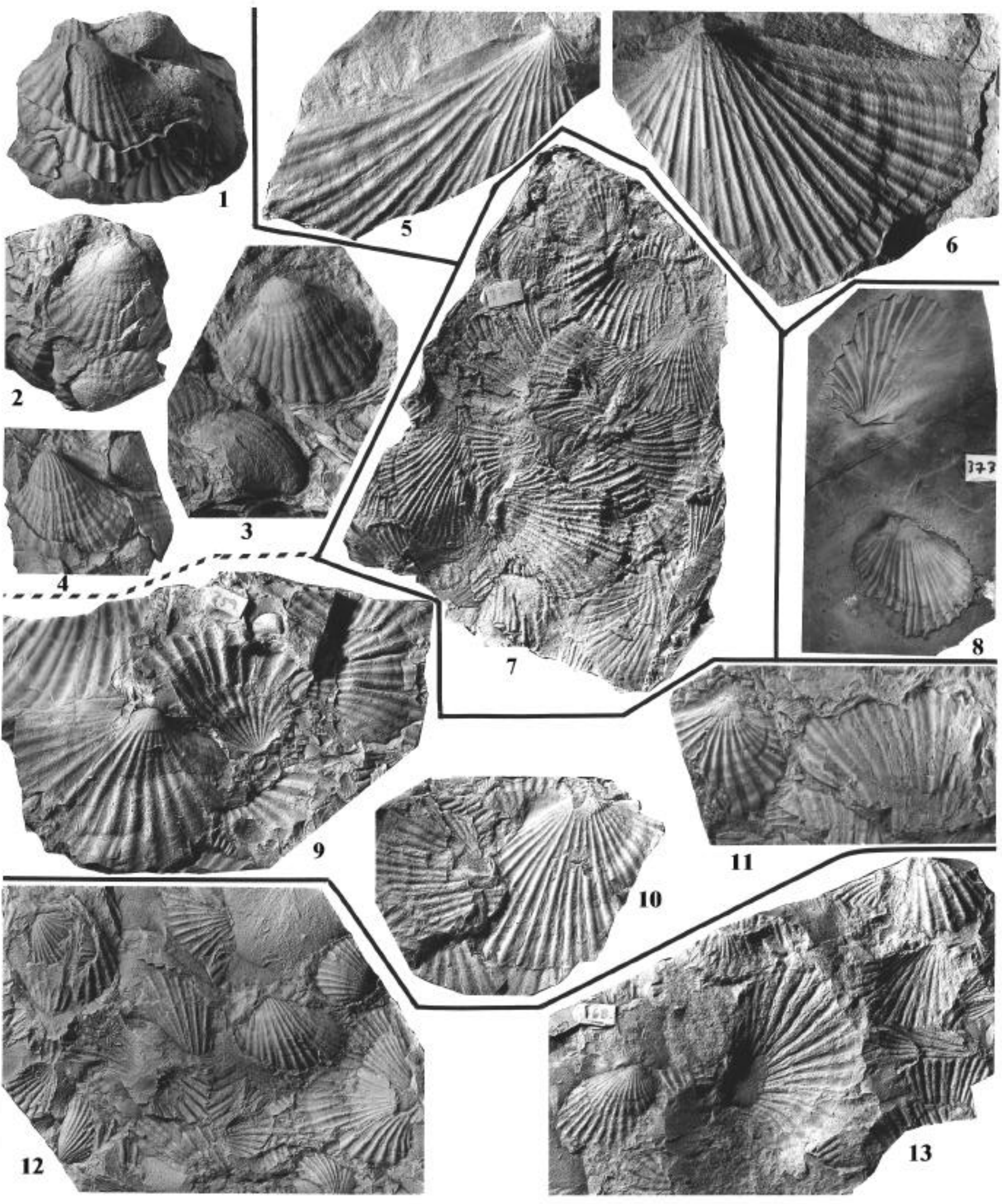




\section{PLATE 10}

[All figures natural size]

Figures 1-6. Monotis from USGS Mesozoic loc. M5059 (a $17 \mathrm{~m}$ stratigraphic interval separated by about $6 \mathrm{~m}$ from top of the Shublik Formation at Fire Creek, the reference section of the formation; see also pl. 11, figs. 1-10).

1-4, 6. M. (Eomonotis) ?jakutica. Left valves and right valve.

5. M. (Eo.) n.sp. aff. M. (Eo.) inaequivalvis. Left valve.

7-12. Monotis (Eomonotis) obtusicostata and associated M. (Eo.) ?jakutica. USGS Mesozoic loc. M6674 (collected from single bed).

7-9, 12. M. (Eo.) obtusicostata. Left valves, especially figure 8 and upper right side of figure 12; right valves, especially upper center of figure 7 and lower figure 12.

10-11. M. (Eo.) ?jakutica. Left valves on the right sides of both figures, associated with M. (Eo.) obtusicostata.

13-14. Monotis (Eomonotis) obtusicostata. USGS Mesozoic loc. M6624 (from within $9 \mathrm{~m}$ stratigraphic interval separated by about $6 \mathrm{~m}$ from top of the Shublik Formation at Fire Creek; within few meters of same stratigraphic level as loc. M5059, figs. 1-6). Left and right valves. 


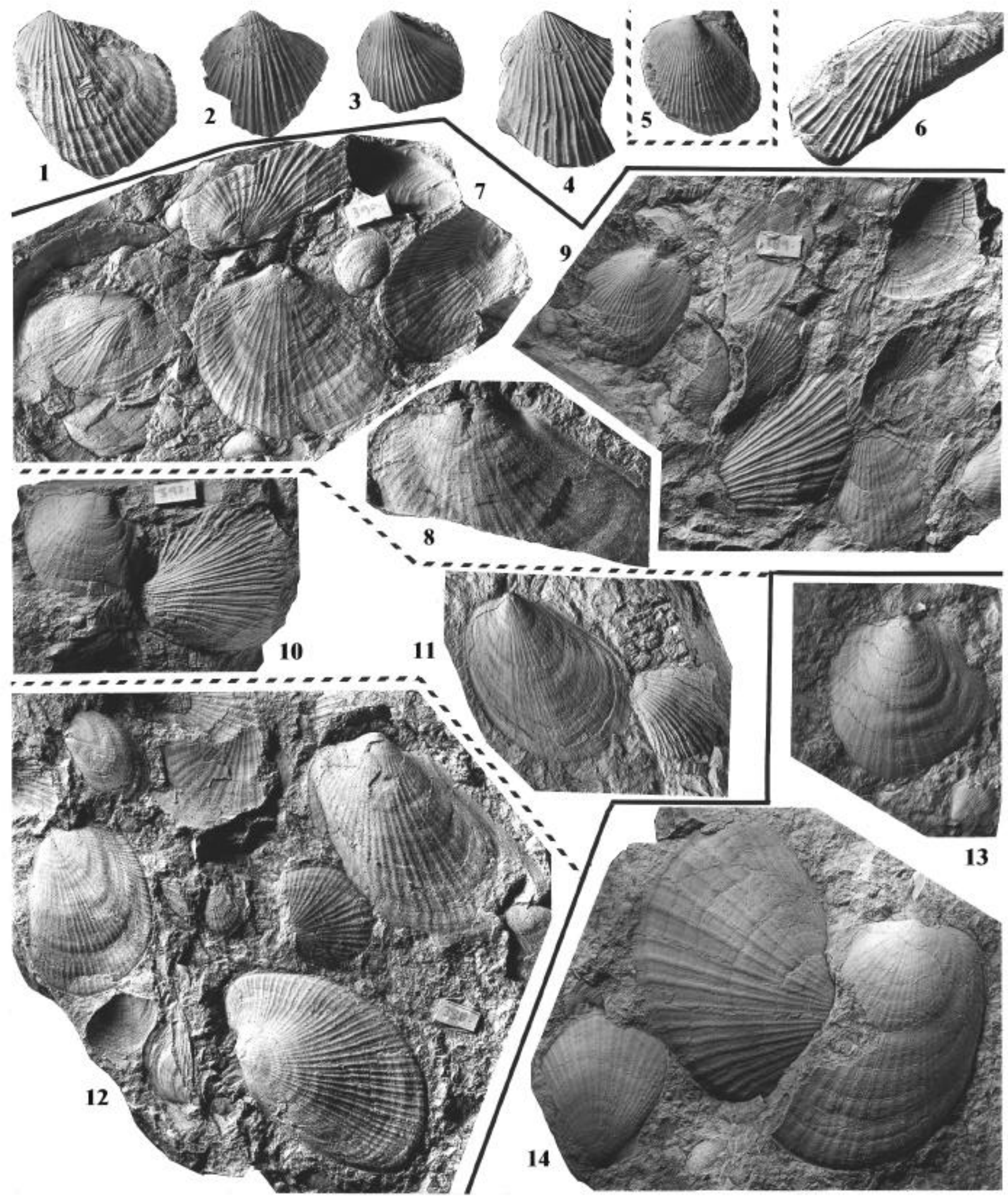




\section{PLATE 11}

[All figures natural size]

Figures 1-12. Monotis from Fire Creek, the reference section of the Shublik Formation (see also pl. 10, figs. 1-6, 13-14).

1-3. M. (Entomonotis) ochotica ochotica. USGS Mesozoic loc. D12594 (basal $1.5 \mathrm{~m}$ of Karen Creek Sandstone). Left valves and right valve (fig. 3).

4-5. M. (En.) ?ochotica ochotica. USGS Mesozoic loc. D12594 (same as figs. 1-3). Left valves.

6-7. M. (En.) ?ochotica ochotica. USGS Mesozoic loc. M5058 (essentially same locality as D12594). Left and right valve.

8-9. M. (Eomonotis) ?pinensis. USGS Mesozoic loc. D12595 (about $2 \mathrm{~m}$ stratigraphically below locs. D12594 and M5058). Left valves.

10-12. M. (Eo.) obtusicostata. USGS Mesozoic loc. M6624 (about 7-8 m below loc. D12595). Left valve (fig. 10) and right valves (figs. 11-12).

13-15. Monotis from core samples, West Dease No. 1 test well, National Petroleum Reserve in Alaska.

13. M. Monotis (Pacimonotis) subcircularis. USGS Mesozoic loc. D12609 (depth 3,915 feet). Left valve.

14-15. M. (Entomonotis) ochotica ochotica. USGS Mesozoic loc. D12610 (depth 3,919.1 feet). Right and left valves.

16-20. Monotis from core samples, Simpson No. 1 test well, National Petroleum Reserve in Alaska.

16. M. (Eomonotis) pinensis. USGS Mesozoic loc. D12613 (depth 6,318.2 feet). Left valve.

17-18. M. (Eo.) n.sp. aff. M. (Eo.) anjuensis. USGS Mesozoic loc. D12614 (depth 6,312 feet, fig. 17) and USGS Mesozoic loc. D12615 (depth 6,310 feet, fig. 18).

19-20. M. (Eo.) typica. USGS Mesozoic loc. D12616 (depth 6,306 feet, fig. 19) and USGS Mesozoic loc. D12617 (depth 6,304 feet, fig. 20). 

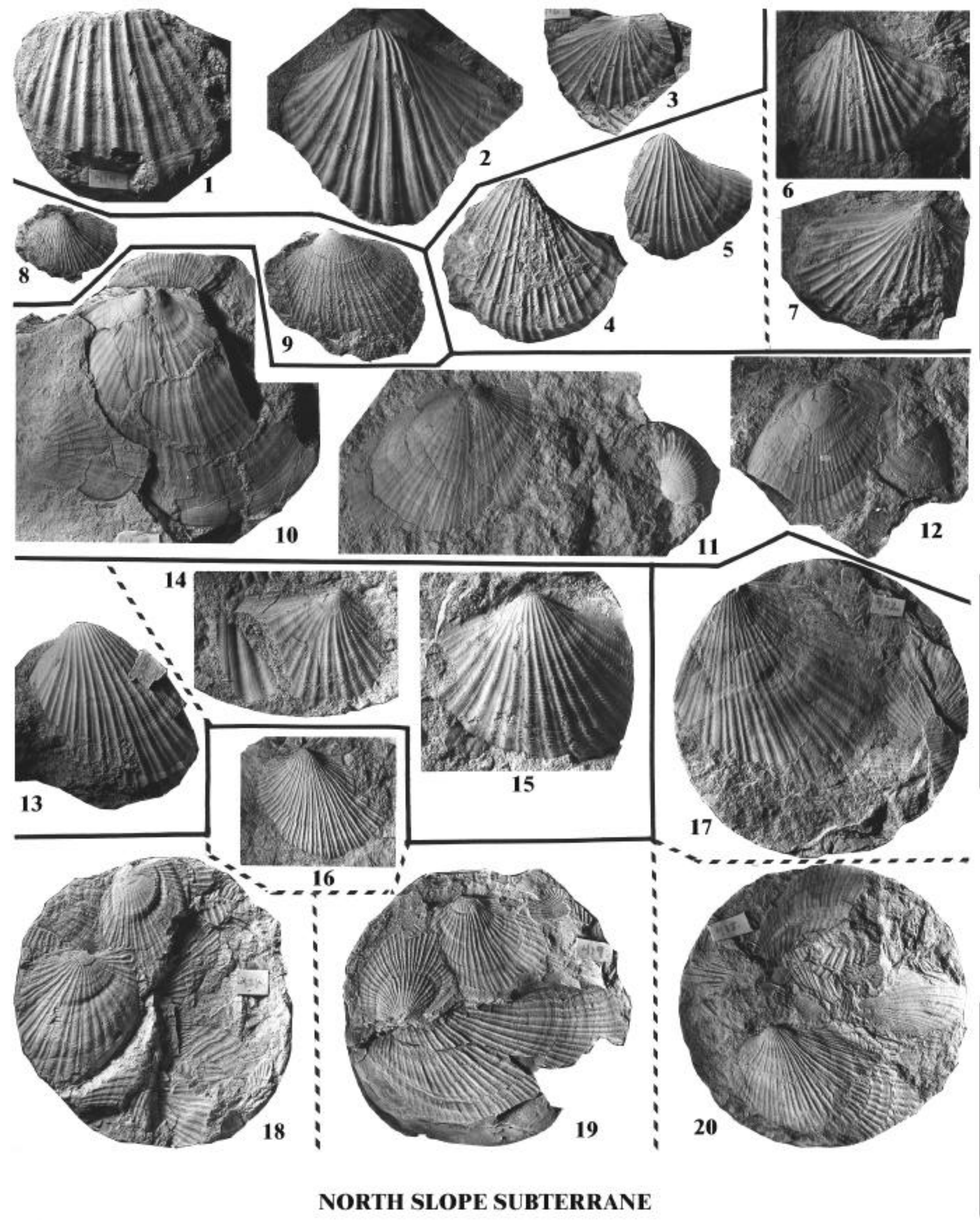